\title{
Synergistic Impairment of the Neurovascular Unit by HIV-1 Infection and Methamphetamine Use: Implications for HIV-1-Associated Neurocognitive Disorders
}

\author{
Nikolai Fattakhov ${ }^{1, *}$, Silvia Torices ${ }^{1}$, Michael Stangis ${ }^{1}$, Minseon Park ${ }^{1}$ and Michal Toborek ${ }^{1,2, *(D)}$ \\ 1 Department of Biochemistry and Molecular Biology, Miller School of Medicine, University of Miami, \\ Miami, FL 33136, USA; sxt736@med.miami.edu (S.T.); mstangis@miami.edu (M.S.); \\ mspark@med.miami.edu (M.P.) \\ 2 Institute of Physiotherapy and Health Sciences, The Jerzy Kukuczka Academy of Physical Education, \\ 40065 Katowice, Poland \\ * Correspondence: nfattakhov@miami.edu (N.F.); mtoborek@med.miami.edu (M.T.); \\ Tel.: +13-052-430-230 (M.T.)
}

Citation: Fattakhov, N.; Torices, S.; Stangis, M.; Park, M.; Toborek, M. Synergistic Impairment of the Neurovascular Unit by HIV-1 Infection and Methamphetamine Use: Implications for HIV-1-Associated Neurocognitive Disorders. Viruses 2021, 13, 1883. https://doi.org/ $10.3390 / \mathrm{v} 13091883$

Academic Editors: Maria Cecilia Garibaldi Marcondes and Marcus Kaul

Received: 30 June 2021

Accepted: 2 September 2021

Published: 21 September 2021

Publisher's Note: MDPI stays neutral with regard to jurisdictional claims in published maps and institutional affiliations.

Copyright: (c) 2021 by the authors. Licensee MDPI, Basel, Switzerland. This article is an open access article distributed under the terms and conditions of the Creative Commons Attribution (CC BY) license (https:/ / creativecommons.org/licenses/by/ $4.0 /)$.

\begin{abstract}
The neurovascular units (NVU) are the minimal functional units of the blood-brain barrier (BBB), composed of endothelial cells, pericytes, astrocytes, microglia, neurons, and the basement membrane. The BBB serves as an important interface for immune communication between the brain and peripheral circulation. Disruption of the NVU by the human immunodeficiency virus-1 (HIV-1) induces dysfunction of the BBB and triggers inflammatory responses, which can lead to the development of neurocognitive impairments collectively known as HIV-1-associated neurocognitive disorders (HAND). Methamphetamine (METH) use disorder is a frequent comorbidity among individuals infected with HIV-1. METH use may be associated not only with rapid HIV-1 disease progression but also with accelerated onset and increased severity of HAND. However, the molecular mechanisms of METH-induced neuronal injury and cognitive impairment in the context of HIV-1 infection are poorly understood. In this review, we summarize recent progress in the signaling pathways mediating synergistic impairment of the BBB and neuronal injury induced by METH and HIV-1, potentially accelerating the onset or severity of HAND in HIV-1-positive METH abusers. We also discuss potential therapies to limit neuroinflammation and NVU damage in HIV-1-infected METH abusers.
\end{abstract}

Keywords: HIV; methamphetamine; neurovascular unit; HIV-associated neurocognitive disorder; blood-brain barrier; neuroinflammation

\section{Introduction}

At the end of 2019, there were an estimated 38 million people living with human immunodeficiency virus (HIV) globally [1]. The introduction of antiretroviral therapy (ART) has significantly transformed the face of HIV type 1 (HIV-1) infection, from a terminal illness to a chronic manageable disease. However, HIV-1-associated neurocognitive disorder (HAND), which ranges from asymptomatic neurocognitive impairments to severe dementia, remains highly prevalent in HIV-1-infected populations, affecting activities of daily living [2]. HAND develops through the initial infiltration of HIV-1-infected immune cells into the brain by crossing the blood-brain barrier (BBB), followed by the initiation of pathogenetic processes, including neuroinflammation, and the establishment of compartmentalized HIV-1 replication in the cells of the neurovascular unit (NVU) including microglia, astrocytes, and pericytes [3-6]. Although endothelial cells and neurons are not permissive to active HIV-1 infection and replication [7], their dysfunction is likely to be caused by indirect pathogenic mechanisms such as HIV-1-altered oxidative balance, leading to increased reactive oxygen species (ROS) generation [8,9]. In addition, HIV-1 proteins, including glycoprotein (gp) 120, transactivator of transcription (Tat), and negative regulator 
factor (Nef), along with elevated levels of proinflammatory mediators can either directly or indirectly lead to neuronal cell death contributing to the persistence of HAND [10-12].

Methamphetamine (METH) is a highly addictive psychostimulant drug, the abuse of which has reached epidemic proportions worldwide, with its use being particularly high among people living with HIV-1 [13]. METH abuse raises the risk of contracting or transmitting HIV-1 and other blood-borne viruses, not only for individuals who inject the drug, but also for noninjecting METH users, as it is associated with an increase in risky sexual behavior [14-17]. METH use, either alone or in combination with other drugs, is associated with failure of viral suppression among HIV-1-seropositive persons on ART, independent of adherence and sociodemographic factors $[18,19]$. Recent findings indicate that HIV-1-infected individuals who engage in METH use display exacerbations in key pathophysiologic processes that are linked to faster clinical HIV-1 progression [20]. A growing body of evidence suggests that the combination of HIV-1 infection and METH dependence causes more profound neurocognitive deficits and structural brain abnormalities than either condition alone [21,22]. Results of a recent study deciphering epigenetic signatures of METH dependence in the human prefrontal cortex of HIV-1-positive individuals suggest that METH use increases genomic activities to become transcriptional events related to neurodegeneration, dopaminergic deficits, and decreased cognitive and executive functions [23]. Considering that BBB breakdown can serve as an early biomarker of human cognitive dysfunction, independent of neurodegeneration markers [24,25], we seek to review how METH abuse may exacerbate BBB breakdown and neuroinflammation within the NVU, resulting in the augmentation of neuronal injuries and worsening of neurocognitive impairment in HIV-1-infected individuals (Figure 1).

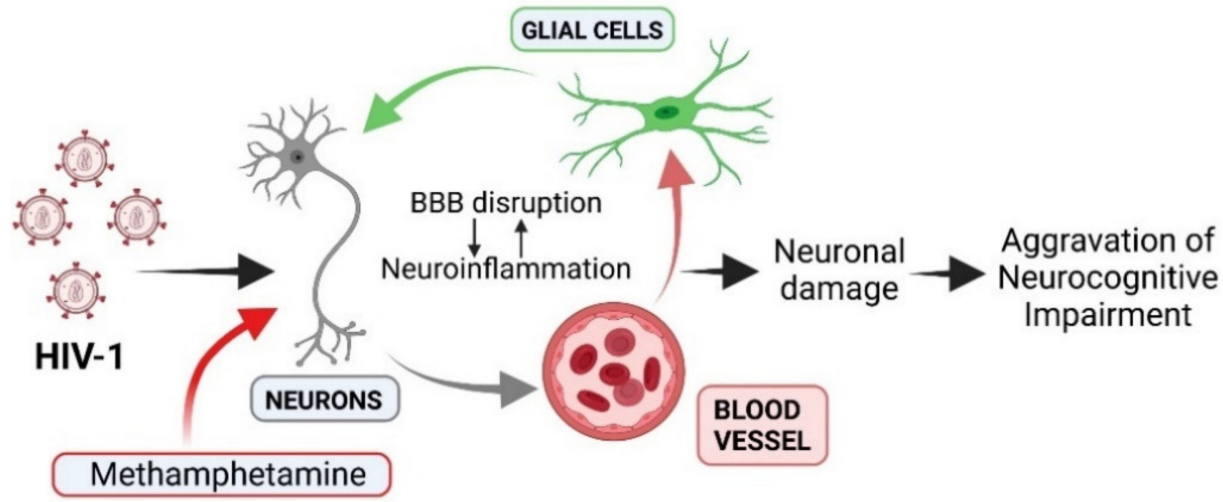

Figure 1. A schematic diagram illustrating a possible contribution of neurovascular unit (NVU) disruption to increased neurocognitive impairment in comorbid HIV-1 infection and methamphetamine (METH) use. The NVU is composed of vascular cells, glial cells, and neurons. METH use and HIV-1 infection compromise blood-brain barrier (BBB) integrity facilitating transmigration of infected immune cells and viral entry across the BBB. This can potentially lead to neuroinflammatory responses by microglia that can further promote BBB disruption. These events result in worsening neuronal damage and aggravating neurocognitive impairments involved in the pathogenesis of HIV-1-associated neurocognitive disorders (HAND). Created with BioRender.com.

The current review aims to summarize the findings from recent human and animal studies which might provide new insights into the pathogenesis of HAND in the context of METH dependence. We will not exhaustively review the literature regarding the impact of HIV-1 infection or METH alone on the NVU, because several excellent reviews summarizing the effects of these factors have recently been published [26-29]. Rather, we will focus on the synergistic molecular mechanisms involved in the neurobehavioral implications of concurrent HIV-1 infection and METH use. The roles of microglia activation and astrocyte dysfunction in comorbid condition will also be discussed, and we will cover 
potential therapeutic strategies to target neurocognitive impairments and minimize NVU dysfunction in HIV-1-infected METH abusers.

\section{Synergistic Impairment of the NVU Induced by Comorbid HIV-1 Infection and Methamphetamine Use}

The NVU incorporates cellular and extracellular components involved in regulating cerebral blood flow and BBB function [30]. The studies showing evidence of synergistic effects of the combination of METH with HIV-1 or HIV-1 neurotoxic proteins on the components of NVU are presented in Table 1. This Table lists in vivo, in vitro, combined in vivo and in vitro studies, as well as postmortem human brain ex vivo studies with indication of viral inoculum dose/route, METH dosing regimen, and experimental model including genetic background of the animals. The chronic METH use pattern including escalating-dose multiple-binge METH regimen was used in all animal studies to more closely mimic a human usage pattern and cause long-term neuronal damage similar to those observed in human METH abusers. Considering that concentrations of HIV-1 proteins used in many in vitro studies are frequently greater than levels found in the cerebrospinal fluid from individuals with HIV-1 infection [31,32], these research findings should be interpreted in the context of the limitations of the experimental paradigms that do not fully mimic pathophysiological changes associated with HIV-1 infection. While some animal studies have utilized simian immunodeficiency virus (SIV) macaque model and mouse model of HIV-1 infection (EcoHIV), other studies rely on models that are solely based on HIV-1 protein toxicity. These models include HIV-1 transgenic (tg) rat and mouse models, intracerebroventricular or intravenous administration of Tat, and tg mouse models expressing a single viral protein, such as Tat or gp120. Non-inducible HIV-1 mice express these viral proteins throughout their lifespan, which can potentially prevent a normal or healthy development before onset of the desired pathological phenotype [33]. The models that are based on a single HIV-1 protein may miss pathological effects that originate from the combined action of different viral proteins encoded by the HIV-1 genome. In general, mouse models that rely on protein toxicity are not infectious and do not reflect the full myriad of HIV-1 infection.

Table 1. A summary of recent studies showing that HIV-1 infection and methamphetamine (METH) use synergistically impair the neurovascular unit (NVU).

\begin{tabular}{|c|c|c|c|c|}
\hline Study and Year & Experimental Model & Viral Inoculum Dose/Route & METH Dosing Regimen & Synergistic Effects on NVU \\
\hline \multicolumn{5}{|c|}{ Combined In Vivo and In Vitro Studies } \\
\hline Huang et al., 2021 [34] & $\begin{array}{c}\text { Tree shrews; HCMEC/D3 } \\
\text { cell line (human) }\end{array}$ & $\begin{array}{l}\text { Tat (100 ng) by tail i.v. injection; } \\
25 \text { to } 200 \mathrm{nM} \text { of Tat }\end{array}$ & $\begin{array}{c}8 \mathrm{mg} / \mathrm{kg} \text { i.p. for } \\
10 \text { consecutive days; } 0.05 \text { to } \\
2.0 \mathrm{mM} \text { for } 24 \mathrm{~h}\end{array}$ & $\begin{array}{l}\text { Enhanced BBB permeability due } \\
\text { to alterations in TRPM2 channels } \\
\text { and TJ protein expression both } \\
\text { in vivo and in vitro }\end{array}$ \\
\hline Li et al., 2021 [35] & $\begin{array}{c}\text { Tree shrews; HCMEC/D3 } \\
\text { cell line (human) }\end{array}$ & $\begin{array}{l}\text { Tat (100 ng) by tail i.v. injection; } \\
100 \text { nM of Tat }\end{array}$ & $\begin{array}{l}8 \mathrm{mg} / \mathrm{kg} \text { i.p. for } \\
10 \text { consecutive days; } 500 \mu \mathrm{M} \\
\text { for } 24 \mathrm{~h}\end{array}$ & $\begin{array}{l}\text { Decreased expression of TJ } \\
\text { proteins and increased BBB } \\
\text { permeability both in vivo and } \\
\text { in vitro; } \\
\text { Downregulation of GLUT1 and } \\
\text { GLUT3 protein expression both } \\
\quad \text { in vivo and in vitro }\end{array}$ \\
\hline Zeng et al., 2018 [36] & $\begin{array}{l}\text { Rats; SH-SY5Y } \\
\text { neuroblastoma cell } \\
\text { line (human) }\end{array}$ & $\begin{array}{l}\text { Tat }(50 \mathrm{ng} / \mathrm{kg}) \text { by tail i.v. } \\
\text { injection; } 50 \text { and } 100 \mathrm{nM} \text { of Tat }\end{array}$ & $\begin{array}{c}10 \mathrm{mg} / \mathrm{kg} \text { i.p. for } \\
7 \text { consecutive days; } 1 \text { and } \\
2 \mathrm{mM} \text { for } 24 \mathrm{~h}\end{array}$ & $\begin{array}{l}\text { Exacerbation of oxidative stress } \\
\text { both in vivo and in vitro }\end{array}$ \\
\hline Park et al., 2021 [37] & $\begin{array}{l}\text { C57BL/ } 6 \text { mice; human } \\
\text { primary neural } \\
\text { progenitor cells }\end{array}$ & $\begin{array}{l}\text { EcoHIV }(1 \mu \mathrm{g} \text { of p24) via left } \\
\text { internal carotid artery injection; } \\
\text { HIV-1 NL4-3 (60 ng/mL of p24) }\end{array}$ & $\begin{array}{l}\text { Escalating dose regimen for } \\
6 \text { days: } 1.0-4.0 \mathrm{mg} / \mathrm{kg} \text { i.p.; } \\
100 \mu \mathrm{M} \text { for } 24 \mathrm{~h}\end{array}$ & $\begin{array}{l}\text { Enhanced neural progenitor cell } \\
\text { proliferation both in vivo and } \\
\text { in vitro }\end{array}$ \\
\hline Yu et al., 2017 [38] & $\begin{array}{l}\text { HIV-1 transgenic rats; } \\
\text { primary human } \\
\text { fetal astrocytes }\end{array}$ & $\begin{array}{c}\text { N/A; HIV-1 BaL (10 ng or } 20 \text { ng } \\
\text { of p24) }\end{array}$ & $\begin{array}{l}10 \mathrm{mg} / \mathrm{kg} \text { i.p. every } 2 \mathrm{~h} \text { for } \\
4 \text { days; } 10,30,100,300 \text { and } \\
1000 \mu \mathrm{M} \text { daily for } 5 \text { days }\end{array}$ & $\begin{array}{l}\text { Induction of astrocyte senescence } \\
\text { both in vivo and in vitro }\end{array}$ \\
\hline
\end{tabular}


Table 1. Cont.

\begin{tabular}{|c|c|c|c|c|}
\hline Study and Year & Experimental Model & Viral Inoculum Dose/Route & METH Dosing Regimen & Synergistic Effects on NVU \\
\hline \multicolumn{5}{|c|}{ In Vivo Studies } \\
\hline Li et al., 2018 [39] & Sprague-Dawley rats & Tat $(50 \mathrm{ng})$ i.c.v. & $\begin{array}{l}10 \mathrm{mg} / \mathrm{kg} \text { i.p. for } \\
7 \text { consecutive days }\end{array}$ & $\begin{array}{l}\text { Decreased expression of TJ } \\
\text { proteins and increased BBB } \\
\quad \text { permeability; } \\
\text { Exacerbation of oxidative stress } \\
\text { and neuronal damage }\end{array}$ \\
\hline Hoefer et al., 2015 [40] & $\begin{array}{l}\text { HIV-1 gp120 } \\
\text { transgenic mice }\end{array}$ & $\mathrm{N} / \mathrm{A}$ & $\begin{array}{l}\text { Escalating dose multiple-binge } \\
\text { regimen for } 25 \text { days: } \\
0.1-6.0 \mathrm{mg} / \mathrm{kg} \text { s.c. }\end{array}$ & $\begin{array}{l}\text { Reduction in post-tetanic } \\
\text { potentiation in hippocampal slices; } \\
\text { Decreased dendritic spine density }\end{array}$ \\
\hline $\begin{array}{l}\text { de Guglielmo et al., } \\
2015 \text { [41] }\end{array}$ & HIV-1 transgenic rats & $\mathrm{N} / \mathrm{A}$ & $\begin{array}{c}\text { Escalating dose multiple-binge } \\
\text { regimen for } 15 \text { consecutive } \\
\text { sessions: } 0.5 \mathrm{mg} / \mathrm{kg} / 0.1 \mathrm{~mL} \\
6 \mathrm{~h} / \text { day i.v. }\end{array}$ & $\begin{array}{c}\text { Gene expression changes } \\
\text { indicative of an increase in } \\
\text { neuronal damage } \\
\text { and impaired aerobic glucose } \\
\text { metabolism in the medial } \\
\text { prefrontal cortex }\end{array}$ \\
\hline $\begin{array}{l}\text { Ohene-Nyako et al., } \\
2018 \text { [42] }\end{array}$ & HIV-1 transgenic rats & $\mathrm{N} / \mathrm{A}$ & $\begin{array}{l}0.02-0.04 \mathrm{mg} / \mathrm{kg} / 0.05 \mathrm{~mL} \text { i.v. } \\
\text { infusion } 2 \mathrm{~h} / \text { day for } 21 \text { days }\end{array}$ & $\begin{array}{l}\text { Upregulation of DRD1 and } \\
\text { deltaFosB expression in the } \\
\text { nucleus accumbens }\end{array}$ \\
\hline Baek et al., 2020 [43] & $\begin{array}{l}\text { Doxycycline-inducible } \\
\text { HIV-1 Tat transgenic mice }\end{array}$ & $\mathrm{N} / \mathrm{A}$ & $\begin{array}{l}2 \mathrm{mg} / \mathrm{kg} \text { i.p. once a day for } \\
7 \text { days (acquisition phase); } \\
1 \mathrm{mg} / \mathrm{kg} \text { (challenge phase) }\end{array}$ & $\begin{array}{l}\text { Reduction in DRD2 and DRD5 } \\
\text { mRNA levels in the striatum }\end{array}$ \\
\hline Najera et al., 2016 [44] & Rhesus macaques & $\begin{array}{l}\text { SIVmac251 i.v. (infectious dose } \\
\text { was not reported) }\end{array}$ & $\begin{array}{l}\text { Escalating dose regimen for } \\
23 \text { weeks with a final dose } \\
\text { of } 2.5 \mathrm{mg} / \mathrm{kg} \text { i.m. }\end{array}$ & $\begin{array}{l}\text { Upregulation of genes encoding } \\
\text { proteins involved in DNA damage } \\
\text { and senescence in microglia }\end{array}$ \\
\hline Niu et al., 2020 [45] & Rhesus macaques & $\begin{array}{l}\text { SIVmac251 i.v. (infectious dose } \\
\text { was not reported) }\end{array}$ & $\begin{array}{l}\text { Escalating dose regimen over a } \\
\text { month-long period: } \\
0.1-2.5 \mathrm{mg} / \mathrm{kg} \text { i.m. }\end{array}$ & $\begin{array}{l}\text { Upregulation of genes encoding } \\
\text { proteins involved in cell death } \\
\text { pathways and deficiencies in the } \\
\text { BDNF-signaling pathway in brain } \\
\text { microglia/macrophages }\end{array}$ \\
\hline \multicolumn{5}{|c|}{ Postmortem Human Brain Ex Vivo Studies } \\
\hline $\begin{array}{l}\text { Soontornniyomkij et al., } \\
2016 \text { [22] }\end{array}$ & $\begin{array}{l}\text { Human postmortem brain } \\
\text { samples }\end{array}$ & $\mathrm{N} / \mathrm{A}$ & Lifetime METH dependence & Focal cerebral microgliosis \\
\hline Doulias et al., 2021 [46] & $\begin{array}{l}\text { Human postmortem brain } \\
\text { samples }\end{array}$ & $\mathrm{N} / \mathrm{A}$ & $\begin{array}{l}\text { Duration of METH use was } \\
\text { not reported }\end{array}$ & $\begin{array}{l}\text { Increase in S-nitrosylation of } \\
\text { tricarboxylic acid enzymes }\end{array}$ \\
\hline \multicolumn{5}{|c|}{ In Vitro Studies } \\
\hline Patel et al., 2017 [47] & $\begin{array}{l}\text { HCMEC/D3 cell line } \\
\text { (human) }\end{array}$ & Tat $(100 \mathrm{nM})$ & $10 \mu \mathrm{M}$ for $24 \mathrm{~h}$ & $\begin{array}{c}\text { Reduced ZO-1 TJ protein } \\
\text { expression (in line with in vivo } \\
\text { studies }[34,35,39] \text { ); } \\
\text { Increased rhodamine } \\
123 \text { accumulation }\end{array}$ \\
\hline Cao et al., 2016 [48] & $\begin{array}{c}\text { Simian virus } 40 \\
\text { (SV40)-transformed } \\
\text { astrocyte cell line (human) }\end{array}$ & gp120 (400 pM) & $500 \mu \mathrm{M}$ for $24 \mathrm{~h}$ & Autophagy initiation \\
\hline $\begin{array}{l}\text { Castellano et al., } \\
2016 \text { [49] }\end{array}$ & $\begin{array}{l}\text { Human primary mixed } \\
\text { cultures of neurons } \\
\text { and astrocytes }\end{array}$ & $\begin{array}{l}\text { HIV-1 ADA (infectious dose } \\
\text { was not reported) }\end{array}$ & $\begin{array}{c}1 \text { and } 10 \mu \mathrm{M} \text { for } 7,14 \text { and } \\
21 \text { days }\end{array}$ & Enhancement of apoptosis \\
\hline $\begin{array}{l}\text { Teodorof-Diedrich et al., } \\
2020[50]\end{array}$ & Human primary neurons & $\begin{array}{l}\text { gp120, Tat or gp120/Tat } \\
(100 \mathrm{ng} / \mathrm{mL})\end{array}$ & $300 \mu \mathrm{M}$ for $24 \mathrm{~h}$ & $\begin{array}{l}\text { DRP1-dependent mitochondrial } \\
\text { fragmentation; } \\
\text { Neurite length reduction (in line } \\
\text { with in vivo study [50]) }\end{array}$ \\
\hline Li et al., 2018 [51] & $\begin{array}{l}\text { Tree shrew primary } \\
\text { midbrain neuronal cells }\end{array}$ & Tat (50 nM and $100 \mathrm{nM}$ ) & $\begin{array}{l}0.1-0.5 \mathrm{mM} \text { at varying time } \\
\text { periods }\end{array}$ & Autophagy initiation \\
\hline Liu et al., 2017 [52] & $\begin{array}{l}\text { Cultured rat } \\
\text { microglial cells }\end{array}$ & gp120 $(0.1,0.5$ and $1.5 \mathrm{nM})$ & 2,20 , and $200 \mu \mathrm{M}$ for $24 \mathrm{~h}$ & $\begin{array}{c}\text { Induced KV1.3 potassium channel- } \\
\text { mediated microglial neurotoxicity; } \\
\text { Increased caspase-3/7 activity in } \\
\text { microglia (in line with in vivo } \\
\text { studies }[52,53] \text { ) }\end{array}$ \\
\hline
\end{tabular}

BBB: blood-brain barrier; BDNF: brain derived neurotrophic factor; DRD1: dopamine receptor D1; DRD2: dopamine receptor D2; DRD5: dopamine receptor D5; DRP1: dynamin-related protein 2; FOXO3: forkhead box O transcriptional factor; GLUT1: glucose transporter 1; GLUT3: glucose transporter 3; i.c.v.: intracerebroventricular; i.m.: intramuscular; i.p.: intraperitoneal; i.v.: intravenous; METH: methamphetamine; NVU: neurovascular unit; ROS: reactive oxygen species; s.c.: subcutaneous; TJ: tight junction; TRPM2: transient receptor potential melastatin 2; ZO-1: zona occludens-1.

\subsection{Disruption of Tight Junctions and Transporters of Brain Endothelial Cells}

The BBB is a complex structure composed of a tightly sealed monolayer of brain microvascular endothelial cells (BMECs) endowed with barrier properties, the basement membrane, and other NVU cells, including astrocytes and pericytes that wrap the ablu- 
minal capillary surface and provide physical support and stability to the BBB [54]. One of the primary properties of the BBB is the strict regulation of paracellular permeability, due to the presence of junctional complexes, which include tight junctions (TJs), adhering junctions, and gap junctions. TJs form the basic structure of the BBB and are composed of three major classes of transmembrane proteins, including occludin, claudins and junctional adhesion molecules, and additional scaffold proteins. Occludin maintains cell surface polarity through interactions with scaffold protein zonula occludens 1 (ZO-1) and contributes to the permeability of endothelial cells [55]. Junctional adhesion molecule A (JAM-A) is an integral transmembrane protein with numerous functions, including restricting vascular permeability by enhancing the expression of claudin-5, the most enriched TJ protein [56]. Alterations in expression and/or localization of any individual constituent TJ proteins, but primarily claudin- 5 , can significantly affect BBB properties, particularly barrier permeability, which indicates their critical importance for the maintenance of the central nervous system (CNS) homeostasis [57]. For example, decreased expression or redistribution of claudin- 5 has been implicated in neurodegenerative and neuroinflammatory disorders, as well as in psychiatric diseases [58,59].

To enter the CNS, METH and HIV-1 must first break through the BBB. Interestingly, METH and HIV-1 appear to compromise BBB integrity in a synergistic manner (Figure 2). Recent studies revealed that HIV-1 Tat and METH are able to synergistically damage the BBB by decreasing expression of TJ proteins including occludin, claudin-5, ZO-1, and JAMA in the cerebral cortexes of tree shrews and rats [34,35,39]. Moreover, the combination of HIV-1 Tat and METH further increased permeability of the BBB in vivo, as determined by the accumulation levels of Evans blue and fluorescein sodium in these studies. On the other hand, a study on METH self-administering HIV-tg rats did not reveal any potentiation of BBB damage in the hippocampus [60], a brain region highly vulnerable to HIV-1 infection [61] and METH toxicity [62]. Nevertheless, there were trends for METH to potentiate the impact of Tat on the levels of claudin-5 in that study. Consistent with in vivo findings, exposure of the human brain capillary endothelial cell line HCMEC/D3, representing a well-established in vitro BBB model [63], to the combination of HIV-1 Tat and METH concentrations of $500 \mu \mathrm{M}$ or higher confirmed the downregulation of occludin, JAM-A, and ZO-1 TJ proteins $[34,35]$. However, these in vitro studies reporting BBB breakdown employ METH at concentrations that are in excess of the range of METH plasma concentrations in drug abusers. In fact, such high METH levels can be associated with lethality [64]. The exposure of Tat-treated HCMEC/D3 cells to a lower dose of METH $(10 \mu \mathrm{M})$ that is likely to reflect relevant METH plasma levels resulted only in a decrease in ZO-1 levels, promoting reduced BBB integrity [47]. On the other hand, METH can accumulate in the brain [65,66]; therefore, higher concentrations of METH in studies that employ astrocytes or microglial cells appear to be more appropriate. The mechanisms of HIV-1 and/or METH-mediated disruption of TJ integrity are now fully understood; however, they may involve alterations of Rho signaling [67], enhanced matrix metalloproteinase activity [68], alterations of the Arp2/3 complex-regulated actin rearrangement [69], and induction of oxidative stress [70]. Indeed, it is very well accepted that endothelial cells are sensitive to oxidative stress-induced dysfunction [71,72].

The presence of numerous luminal and abluminal protein transporters, solute and ion transporters, and efflux transporters strictly controls the entry and exit of molecules and metabolic by-products across the BBB. It has been shown that HIV-1 Tat protein and METH synergistically impaired the functions of two major glucose transport proteins, GLUT1 and GLUT3 in the brain endothelium of tree shrews [34]. This resulted in decreased glucose uptake and contributed to the disruption of BBB integrity and function. In the brain, GLUT1 predominantly mediates glucose transport across the BBB into astrocytes, whereas GLUT3 provides glucose to neurons [73,74]. Therefore, the impairment of GLUT1 at the brain endothelium caused by METH may contribute to energy-associated disruption of TJ assembly and loss of BBB integrity [75]. Influx and efflux transporters, which extrude toxic metabolites from endothelial cells and limit CNS entry of xenobiotics and 
therapeutics from the bloodstream, are also a prominent feature of the BBB. Despite the considerable number of studies focused on transport mechanisms that limit BBB drug penetration, it is uncertain the extent to which HIV-1- and METH-induced alterations in ART penetration into the brain resulted from compromised BBB integrity or disrupted efflux transporter function. Several antiretroviral drugs used in the treatment of HIV-1 infection are substrates for P-glycoprotein (P-gp), a major adenosine triphosphate (ATP)-binding cassette transporter, responsible for the extrusion of substrates from the brain back into the blood. One recent study showed that exposure of HCMEC/D3 cells to a combination of Tat and METH resulted in increased cellular accumulation of the P-gp substrate rhodamine 123, suggesting that P-gp was inhibited or that its function was impaired within these cells [47]. Interestingly, the expression and efflux function of P-gp has been reported to be upregulated by Tat [76]. This might explain why HIV-1-infected individuals maintained on suppressive therapy present with low levels of ART in the brain [77]. A better understanding of the mechanism of combined impact of HIV-1 and METH on P-gp may offer solutions to improve the efficiency of ART to reach the brain HIV-1 reservoirs or to enhance the ability of ART to cross the BBB.

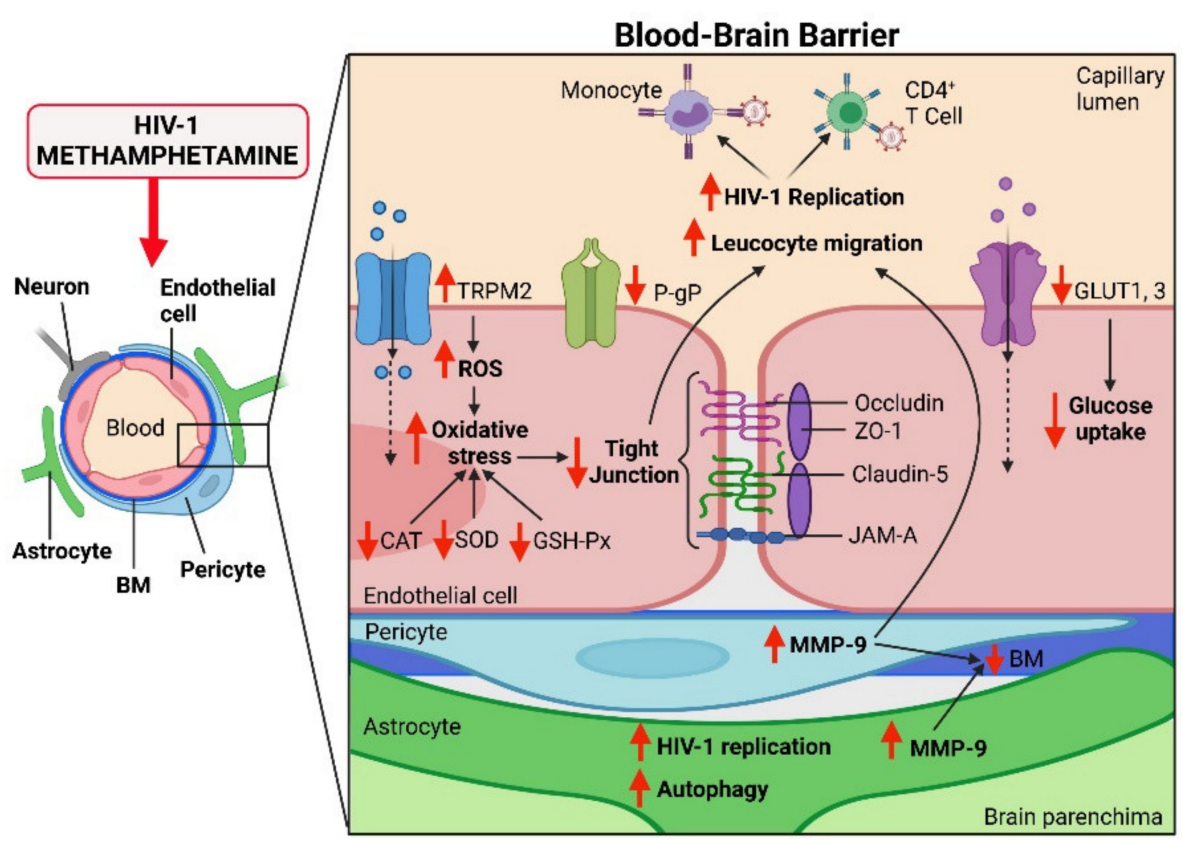

Figure 2. Synergistic impact of HIV-1 infection and methamphetamine (METH) use on the bloodbrain barrier (BBB). The main component of the BBB is endothelial cells, which are bridged by tight junction (TJ) protein complexes. Illustrated are four critical TJ proteins that are synergistically affected by comorbid HIV-1 infection and METH: occludin, zonula occludens 1 (ZO-1), claudin-5, and junctional adhesion molecule-A (JAM-A). In addition, HIV-1 infection and METH synergistically affect carrier-mediated transport across the BBB by impairing the functions of P-glycoprotein (P-gp) and two glucose transport proteins, GLUT1 and GLUT3. METH and HIV-1 also synergistically induce oxidative stress via activation of transient receptor potential melastatin 2 (TRPM2) channels in endothelial cells. The combination of METH and HIV-1 infection induces excessive production of reactive oxygen species (ROS) and impairs the defensive abilities of antioxidant enzymes catalase (CAT), glutathione peroxidase (GSH-PX), and superoxide dismutase (SOD). Elevated activity of matrix metalloproteinase-9 (MMP-9) leads to the degradation of the basement membrane (BM). Increased BBB permeability due to degradation of TJs and BM proteins may facilitate transmigration of HIV-1-infected monocytes and CD4+ T cells into the brain. METH enhances HIV-1 replication in HIV-1 infected CD4+ T cells, likely stimulating transmigration of infected immune cells across the BBB. HIV-1 replication can be enhanced by METH, contributing to increased viral load in the brain. Created with BioRender.com. 


\subsection{Oxidative Stress and Inflammation}

Clinical evidence shows that exposure of endothelial cells to HIV-1 is linked to endothelial dysfunction [7]. Molecular in vitro and in vivo studies have shown that this is at least partially mediated by the impact of HIV-1 cellular infection and HIV-1 proteins on the enzymatic sources of oxidative stress in the vascular wall $[27,78]$. The role of individual effects of METH in the disruption of BBB function by induction of oxidative stress and inflammatory signaling has been also widely recognized [70,79]. A recent study examining how METH can affect the metabolic pathways within the NVU indicated that endothelial cells and neural cells exhibited much higher levels of cellular stress compared to astrocytes and pericytes [80]. A proteome analysis from this study revealed that METH can upregulate stress-activated protein kinase/c-Jun N-terminal kinase (SAPK/JNK) activation pathways, inflammatory pathways, and growth factor signaling pathways including platelet-derived growth factor (PDGF) signaling in human primary BMECs. Results from tree shrew experiments showed that METH and HIV-1 Tat co-induced the oxidative stress response at the $\mathrm{BBB}$, reducing catalase (CAT), glutathione peroxidase (GSH-PX), and superoxide dismutase (SOD) activity, as well as increasing ROS levels [35]. In addition, abnormal endothelial cell morphology and increased apoptosis were found in that study. It was proposed that synergistic elevation of the expression of transient receptor potential melastatin 2 (TRPM2) in the prefrontal cortex contributed to the observed effects [35]. Indeed, TRPM2 channels can mediate the oxidative stress reactions via activation of nucleotide-binding oligomerization domain-like receptor family pyrin domain, containing 3 (NLRP3) inflammasomes, microglia activation, or inducing production of tumor necrosis factor- $\alpha$ [81,82]. Oxidative stress, in turn, can cause a rapid induction of autophagy in human brain vascular pericytes by tyrosine nitration of TRPM2, negatively affecting the BBB [83].

\subsection{Alterations in Astrocytes and Pericytes}

In vivo studies have failed to demonstrate HIV-1 replication in endothelial cells, suggesting that the mechanism accounting for endothelial damage may partially rely on the indirect action of molecules released to the microenvironment by other infected cells in the brain [7], such as astrocytes and pericytes. Astrocyte endfeet cover over $90 \%$ of the endothelial cell surface, and release specific factors that modulate the permeability of the BBB $[84,85]$. Astrocyte loss in the adult mouse brain has been shown to cause BBB damage of varying extents $[86,87]$. Accumulating evidence suggests that astrocytes support productive HIV-1 infection in vivo [4]. A significant increase in the release of HIV-1 p24 protein by primary human astrocytes was observed upon METH treatment [88], suggesting a role for METH in enhancing viral replication in astrocytes. Another recent study revealed that METH and HIV-1 gp120 caused an increase in levels of the autophagosomal marker LC3-II in astrocytes, and the level of LC3-II was further increased when the cells were treated with METH and gp120 in combination [48]. However, prolonged concurrent treatment exacerbated astrocyte death accompanied by the inhibition of autophagy, suggesting that autophagy might function as a protective response against apoptosis caused by a combined impact of METH and gp120.

Pericytes are a type of vascular cell that wrap the cerebral capillary walls and play a critical role in the regulation of the BBB [89]. Signals from brain pericytes regulate the expression of genes in endothelial cells that influence transendothelial permeability and enhance astrocyte endfeet/endothelial contacts [90]. BBB pericytes can be productively infected with HIV-1 and are prone to establishing a latent infection in the brain [3]. Dysfunctional pericyte-endothelial interactions and pericyte loss have been suggested to contribute to SIV-induced BBB disruption and neuropathogenesis in HAND [91,92]. Studies from our laboratory also demonstrated that the propagation of HIV-1 infection in human brain pericytes is mediated by enhancing gap junction-mediated intercellular communication and may contribute to BBB dysfunction [93]. Moreover, our recent work suggests that occludin can control HIV-1 transcription in brain pericytes via regulation of sirtuin-1 activation and cooperation with caveolin-1 and Alix [94,95]. 
The toxic effects of METH on pericytes have been previously reported in several in vitro studies. For example, METH has been shown to increase the migration of pericytes from the endothelial basement membrane via activation of p53 upregulated modulator of apoptosis and sigma-1 receptor [96]. Another study identified that the inflammatory pathways were not activated in human brain pericytes upon METH exposure, while signaling pathways involving nerve growth factor (NGF) and fibroblast growth factors (FGF) were upregulated [80]. We did not identify any published research that linked HIV-1 infection and METH use in brain pericytes. It has recently been discovered that primary brain pericytes infected with HIV-1 are highly susceptible to DNA damage in the presence of glutamate [97]. Based on this information, we hypothesize that increased extracellular glutamate levels seen in HIV-1 and METH comorbidity [49] might contribute to reduced pericyte coverage in this condition.

\subsection{Facilitation of Immune Cell Transmigration across the BBB}

A number of previous studies have shown that METH has the ability to disrupt immune homeostasis, affecting diverse leukocyte subsets, and thereby making METH users more susceptible to HIV-1 infection [98]. In humans, significantly higher viral loads have been reported in the plasma of HIV-1-infected subjects with a history of METH abuse, as compared with HIV-1-infected individuals not using METH [99]. METH has been shown to elevate monocyte activation [100] and enhance HIV-1 replication in monocytederived macrophages [101] and $\mathrm{CD}^{+}$T-cells in vitro [102,103], the primary targets for the virus. Since HIV-1 and METH can independently negatively affect BBB integrity and permeability, combined HIV-1 and METH insults may facilitate leukocyte extravasation from blood to brain. Increased brain viral load was found in rhesus monkeys infected with SIV and exposed to METH [104]. METH has been suggested to increase infectivity of myeloid cells in the brain by stimulating dopamine release and modulating the expression of HIV-1 co-receptor CCR5 [105]. A recent study revealed that HIV-1 proteins and METH independently increase matrix metalloproteinase (MMP)-9 in the NVU, possibly through the activation of nuclear factor- $\mathrm{kB}$ (NF- $\mathrm{kB}$ ) [60]. MMP-9 is a protease involved in the degradation of TJs [106], basement membrane proteins [107], and dystroglycan in the astrocyte endfeet [108]. Cyclooxygenase (COX)-2 might be another common target for the detrimental effects of both METH and HIV-1. This enzyme has been revealed to be implicated in compromising BBB integrity by HIV-1 Tat $[109,110]$ and METH [111]. Nevertheless, more efforts need to be directed toward unveiling the signaling pathways that orchestrate leukocyte-endothelial interactions and how they may converge synergistically during HIV-1 and METH comorbidity.

\section{Potentiation of Neuroinflammation by the Combination of HIV-1 Infection and Methamphetamine Use}

\subsection{Mechanisms of Neuronal Dysfunction}

While neuronal injury and loss are at the heart of HAND, HIV-1 does not directly injure neurons by productive infection, but rather by indirect or inflammatory factors released from infected cells in the CNS [9]. HIV-1 infection and METH dependence can amplify neuroinflammation by fostering a dysfunctional crosstalk of neurons with microglia and astrocytes (Figure 3). Neurons communicate via unique structures, dendrites, and axons, to receive and send the electrical signals that make neuronal communication possible. Therefore, unraveling the combined effects of HIV-1 and METH on neural connectivity is of great significance. It has been reported that the cortical neurons of rats treated with a combination of Tat and METH exhibited edematous swelling of axonal membranes, which was larger than in the METH and Tat treated groups [39]. This axon injury, in turn, could affect action potential signal transmission [112] or lead to a reduction in nerve conduction velocity [113]. Besides, gp120 and Tat in combination with METH induced focal swellings of dendrites and reduced the total length of the neuritic network in human primary neurons [50]. Data from animal studies suggested that loss or alteration of dendritic 
spines resulting from METH treatment of HIV-1 gp120 tg mice led to impaired learning and memory [40]. Moreover, there was a marked reduction in staining for microtubule associated protein (MAP)-2, expressed mainly in dendritic extensions in the human primary neurons exposed to HIV-1 expressing microglia cells [114]. In contrast, a large study of postmortem human HIV-1-infected brains from subjects with long-term METH dependence revealed no significant association of METH with dendritic spine loss in the cortex [22].

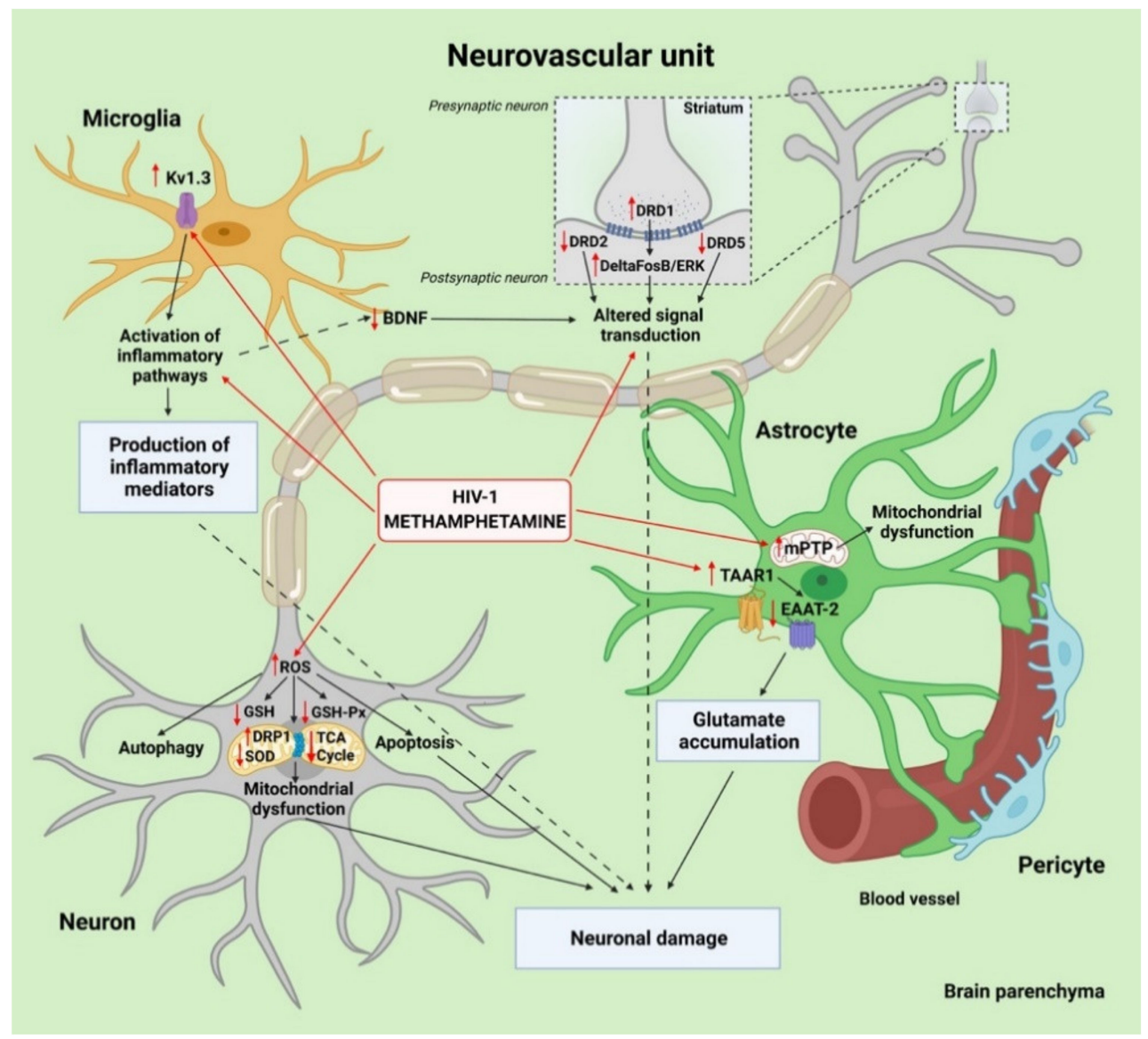

Figure 3. Synergistic cooperation between HIV-1 and methamphetamine (METH) in the neurovascular unit (NVU) potentiates neuroinflammation and enhances neuronal damage. HIV-1 enters the brain via infected monocytes and CD4+ lymphocytes that cross the blood brain barrier (BBB). Once inside the brain, infected macrophages facilitate productive infection and release free virions into the brain parenchyma that infect neighboring microglia and, to some degree, astrocytes and pericytes. This infection leads to the release of neurotoxic factors and to enhanced activation of microglia. METH readily crosses the BBB due to its small size and significantly potentiates neuronal damage, mediated by microglia activation of voltage-gated potassium channel KV1.3. METH also downregulates the release of brain-derived neurotrophic factor (BDNF) from HIV-1-infected microglia. METH and HIV-1 cause astrocyte dysfunction by the opening of mitochondrial permeability transition pores (mPTPs) and modulating TAAR1/EAAT2 signaling pathways involved in glutamate clearance from the extracellular space. The other synergistic effects of METH and HIV-1 include mitochondrial fission mediated by dynamin-related protein 1 (DRP1) and impairment of the tricarboxylic acid (TCA) cycle in neurons. Furthermore, the combination of METH and HIV-1 induces neuronal oxidative damage by downregulating levels of glutathione (GSH), antioxidant defense enzymes glutathione peroxidase (GSH-PX), and superoxide dismutase (SOD). Created with BioRender.com.

Recent studies have demonstrated that chronic exposure to METH exacerbates Tatinduced neurotoxicity, partially due to causing excessive ROS production and impairing antioxidant systems [115]. For example, a study based on human SH-SY5Y neuroblastoma 
cells revealed a strong synergistic effect of the combined METH and Tat treatment on ROS production and the inhibition of protein expression levels of GSH-PX and SOD, key players in antioxidant defense [36]. This study has also provided experimental evidence that concurrent exposure to Tat and METH resulted in greater apoptosis than METH or Tat treatment alone in vivo and in vitro. Another study found that METH can synergistically induce autophagy in primary midbrain neuronal cells of tree shrews [51]. It was also demonstrated that Tat and METH have an additive effect in lowering the levels of glutathione (GSH), which plays critical roles in maintaining the cellular redox status and protecting cells from oxidative damage [39].

Neural tissues depend on mitochondria to produce ATP via the tricarboxylic acid (TCA) cycle, and oxidative phosphorylation (OXPHOS) required for mechanisms that ultimately determine neuronal performance, such as excitability and synaptic signaling [116]. Excessive ROS generation causes oxidative stress injuries not only in the form of lipid peroxidation, protein peroxidation, and DNA damage, but in various forms of mitochondrial dysfunction, such as defects in mitochondrial dynamics and transport, alterations in mitochondrial membrane permeability, dysregulated calcium homeostasis, mitophagy, and compromised ATP production. All these changes further amplify neurodegeneration and may trigger memory and learning impairment. Recent evidence from a mass spectrometry study found that pyruvate carboxylase, which catalyzes the conversion of pyruvate to oxaloacetate, was S-nitrosylated (and thus inhibited) in human postmortem brain samples from HIV-1-positive individuals with HAND and a history of METH use, but not in the HAND brains without METH abuse [46]. This data suggest that pyruvate metabolic processes and respiration may be affected to a greater extent in HAND in the setting of METH use. Moreover, another study demonstrated a reduction in the expression of TCA cycle-related genes, with an increase in glycolysis-related genes, in HIV-1 tg/METH self-administrating rats compared with wild type rats that self-administered METH [41]. The recently discovered association of OXPHOS pathway defects in peripheral blood mononuclear cells with neuroimaging measures of chronically HIV-1-infected individuals independent of METH use history suggested that this type of mitochondrial dysfunction may be more strongly linked to HIV-1 pathogenesis than to METH use [117].

Alterations in mitochondrial dynamics maintained by a balance of fission and fusion is believed to contribute to neurodegeneration. Indeed, any disbalance in mitochondrial dynamics may ultimately lead to the accumulation of either fragmented or hyperfused mitochondria. Dynamin-related protein 1 (DRP1) is the central molecular player that mediates mitochondrial fission. METH has been found to increase mitochondrial fragmentation through translocation of DRP1 in HIV-1-treated human primary neurons [50]. The impaired mitophagy detected in the presence of METH in combination with HIV-1 gp120 or Tat proteins in this study suggests its possible association with the accelerated aging observed in HIV-1-infected individuals. The fact that HIV-1 infection and METH dependence independently and adversely affected the leukocyte telomere to single copy gene ratio, a biomarker for aging and aging-associated diseases, supports this hypothesis [118]. Interestingly, DRP1 has been previously shown to be implicated in the pathogenesis of HAND [119] and HIV-1 encephalitis [120] in postmortem human brain studies, as well as in METH-mediated mitochondrial fragmentation in rat neural progenitor cells [121]. Recent research from our laboratory has presented evidence that exposure to METH increases HIV-1 infectivity in neural progenitor cells [122]. Additionally, our group reported that chronic exposure to METH resulted in enhanced proliferation of neural progenitor cells in the subventricular zone of the hippocampal dentate gyrus in an EcoHIV mouse model [37]. Continuous adult neurogenesis in the subgranular zone can play a neuroprotective role by replacing damaged neurons or glial cells with newly formed cells in response to such stimuli as BBB disruption [123]. METH-associated increase in HIV-1 infectivity of neural progenitor cells, in turn, might have negative long-lasting consequences for these cells, such as abnormal differentiation and spreading HIV-1 latency in the CNS. 
Alterations in the dopaminergic system have long been associated with HIV-1 infection in the CNS [124]. METH, in turn, produces long-term damage to dopaminergic and serotonergic axon terminals in the striatum, hippocampus, and prefrontal cortex [42]. The dopamine D1 receptor (DRD1) and its targets were explored in METH-sensitized HIV1 Tat tg rodent models. The nucleus accumbens, the brain region involved in reward processing and drug addiction, exhibited increased DRD1 immunoreactivity along with a significant increase in the addiction-associated transcription factor deltaFosB in METH self-administering HIV-1 tg rats, as compared with saline or METH-exposed wild-type rats [43]. In contrast, no changes in DRD1 stimulation or deltaFosB levels were found in the hippocampi of METH-treated HIV-1 tg rats [60], indicating region-specific alterations. The nucleus accumbens is crucial to drug-induced conditioned place preference and structural plasticity [125], and it has higher densities of DRD1-expressing neurons as compared to the hippocampus [126]. Furthermore, METH treatment markedly reduced dopamine D2 receptor (DRD2) and dopamine D5 receptor (DRD5) mRNA levels in the mouse striatum. This effect was further increased by Tat expression, especially in females exposed to METH [127]. These findings were consistent with the data from two recent meta-analyses that indicated significantly decreased D2/D3 receptor availability and transporter density in the striatum of METH users [128,129].

\subsection{Contribution of Microglia and Astrocytes to Neuroinflammation}

There is substantial evidence that inflammatory responses mediated by the activation of microglia are major drivers for the development and progression of HAND as well as METH-induced neurotoxicity $[42,53,114]$. A higher density of activated microglia within the temporoparietal cortex, a brain region important for numerous aspects of social cognition, was observed in HIV-1-infected individuals with lifetime METH dependence [22]. The findings from a recent gene expression profiling study showed a pronounced increase in the activation of immune- and inflammation-related pathways in the medial prefrontal cortex of HIV-1 tg rats with a history of escalated METH self-administration under longaccess conditions [41]. One of the mechanisms that triggers microglia neurotoxic activity by METH in the context of HIV-1 could be related to a strong effect of METH on the transcription of genes associated with inflammation and chemotaxis pathways, especially CXCR4 and CCR5, which function as co-receptors for HIV-1 entry [44]. Moreover, METH potentiates HIV-1 gp120-induced microglia neurotoxic activity via voltage-gated potassium channel Kv1.3 and caspase 3/7 signaling [52]. Genes encoding functions in cell death pathways were shown to be overexpressed in microglia cells from the brains of rhesus monkeys with productive SIV infection treated with METH, as compared to SIV-infected animals not exposed to METH, and deficiencies in the brain-derived neurotrophic factor (BDNF) signaling pathway were predicted in this study [45]. In addition, the expression of the gene encoding suppressor cytokine signaling 1 (SOCS1), a marker of DNA damage and senescence, was significantly increased in SIV-infected microglia treated with METH as compared to SIV-infected microglia [44]. These METH-induced transcriptional changes confirm the role of METH abuse in promoting a proinflammatory environment in the brain.

Astrocytes provide trophic support for neurons and are involved in the regulation of transmission and synaptic activity, therefore an impairment in astrocyte function can negatively impact neurons. The mechanisms by which HIV-1 and METH lead to astrocytic neurotoxic activity are not entirely clear. A recent study demonstrated that acute treatment with HIV-1 led to the opening of mitochondrial permeability transition pores in the inner mitochondrial membrane in METH-cotreated primary human astrocytes [130]. Another study pointed to the induction of significant senescence of primary human fetal astrocytes mediated by the $\beta$-catenin pathway, which leads to neuronal toxicity in HIV- 1 and METH comorbidity [38]. Emerging evidence suggests that cell senescence plays an important role in aging-associated diseases, including neurodegenerative diseases [131].

It has been proposed that METH use disorder exacerbates HAND partly through amplifying glutamate dysregulation of astrocytes, resulting in excessive release of glutamate 
to the CNS microenvironment. Chronic excess of extracellular glutamate acts as a neurotoxin, triggering neuronal oxidative stress and DNA damage [132]. When HIV-1-infected cultures of human neurons and astrocytes were treated with METH, a further increase in glutamate dysregulation, as well as increased apoptosis of both cell types was observed, and METH-induced changes in astrocytic gap junctions contributed to this process [49]. Recent work indicated that METH-induced downregulation of astrocytic excitatory amino acid transporter-2 (EAAT2), which is responsible for more than $90 \%$ of glutamate uptake from the synaptic environment, was exacerbated by interleukin-1 $\beta$ (IL-1 $\beta$ ) in primary human astrocytes [133]. IL-1 $\beta$ has been shown to be important for HIV-1 pathobiology [102]. Moreover, EAAT2 was found to be S-nitrosylated in the HAND human brain [46]. The METH-induced EAAT2 dysfunction in astrocytes is mediated by trace amine associated receptor 1 (TAAR1). METH-induced transcription factor cyclic AMP response-binding protein (CREB) phosphorylation has been suggested as a critical mechanism for EAAT2 expression regulation, and may thus serve as a mechanistic target for the METH-induced TAAR1 activation, associated with impaired glutamate clearance capabilities in the context of HAND [133].

\section{Combined Effects of HIV-1 Infection and Methamphetamine Use on Neurocognitive Functioning}

Table 2 summarizes the recent human and rodent studies linking the combination of HIV-1 infection and METH use to the alteration of neurocognitive function and behavior. The human studies involved neuropsychological testing across various cognitive domains in adult participants with the presence or absence of HIV-1 infection and METH dependence. The results from a recent meta-analysis consisting of 37 studies suggested that working memory is perhaps the most significantly affected cognitive component of executive function among HIV-1-infected individuals in the ART era [134]. In animal studies, combined Tat expression and METH exposure increased perseverative errors during reversal learning in mice, suggesting impaired cognitive flexibility [135]. It was also indicated that administration of METH to HIV-1 Tat tg mice exacerbated the deficits in working memory and spatial learning characterized by decreased spontaneous alternations in the $\mathrm{Y}$ maze and increased latency time to reach the escape platform in Morris water maze tests, respectively [136]. Decreased levels of BDNF in all investigated brain regions could explain the impaired working memory seen in these experiments.

Table 2. A summary of recent studies exploring the alterations in neurocognitive functioning and behavior due to the combination of HIV-1 infection and methamphetamine (METH) use.

\begin{tabular}{cccc}
\hline \multicolumn{1}{c}{ Study and Year } & Study Design & Experimental Model & Study Outcomes \\
\hline Pocuca et al., 2020 [137] & Cross-sectional & $\begin{array}{c}\text { Human studies } \\
\text { HIV-/METH+, 49 HIV+/METH-, } \\
\text { and 53 HIV+/METH+) }\end{array}$ & $\begin{array}{c}\text { METH, but not HIV-1, was associated with sustained } \\
\text { attention and vigilance deficits. }\end{array}$ \\
\hline Walter et al., 2021 [138] & Cross-sectional & $\begin{array}{c}\text { 205 adults (69 HIV-/METH-, 40 } \\
\text { HIV-/METH+, 52 HIV+/METH-, } \\
\text { and 44 HIV+/METH+) }\end{array}$ & $\begin{array}{c}\text { Prepulse inhibition was most decreased in people } \\
\text { with HIV-1 and a history of METH dependence. }\end{array}$ \\
\hline Minassian et al., 2017 [139] & Cross-sectional & $\begin{array}{c}\text { 172 adults (49 HIV-/METH-, 48 } \\
\text { HIV-/METH+, 37 HIV+/METH-, } \\
\text { and 38 HIV+/METH+) }\end{array}$ & $\begin{array}{c}\text { Additive effects of HIV-1 and METH were not } \\
\text { observed for everyday functioning. }\end{array}$ \\
\hline Paolillo et al., 2019 [140] & Cross-sectional & $\begin{array}{c}\text { 210 adults (92 HIV-/METH-, 75 } \\
\text { HIV+/METH-, and 43 } \\
\text { HIV+/METH+) }\end{array}$ & $\begin{array}{c}\text { Persons with comorbid HIV-1 and METH use } \\
\text { disorder had higher frailty index scores than both } \\
\text { models linked higher frailty index scores to worse } \\
\text { global neurocognition and greater likelihood of } \\
\text { everyday functioning dependence among the } \\
\text { HIV+/METH+ group. }\end{array}$ \\
\hline
\end{tabular}


Table 2. Cont.

\begin{tabular}{|c|c|c|c|}
\hline Study and Year & Study Design & Experimental Model & Study Outcomes \\
\hline \multicolumn{4}{|c|}{ Human studies } \\
\hline Sun-Suslow et al., 2020 [141] & Cross-sectional & $\begin{array}{l}313 \text { adults }(72 \mathrm{HIV}-/ \mathrm{METH}-, 16 \\
\mathrm{HIV}-/ \mathrm{METH}+, 141 \mathrm{HIV}+/ \mathrm{METH}-\text {, } \\
\text { and } 84 \mathrm{HIV}+/ \mathrm{METH}+)\end{array}$ & $\begin{array}{c}\text { HIV+/METH+ individuals endorsed significantly } \\
\text { more problematic sleep than HIV+ and HIV-/METH- } \\
\text { individuals. Poorer reported sleep quality among } \\
\text { HIV+/METH+ was also associated with multiple } \\
\text { adverse functional outcomes including greater } \\
\text { objective cognitive impairment. }\end{array}$ \\
\hline Saloner et al., 2020 [142] & Cross-sectional & $\begin{array}{l}125 \text { adults (23 HIV-/METH-, } 35 \\
\text { HIV-/METH+, } 22 \text { HIV+/METH-, } \\
\text { and } 45 \mathrm{HIV}+/ \mathrm{METH}+)\end{array}$ & $\begin{array}{c}\text { Prevalence of lifetime major depression disorder was } \\
\text { higher in HIV+/METH+ compared with the } \\
\text { other groups. }\end{array}$ \\
\hline Javanbakht et al., 2020 [143] & Longitudinal & $\begin{array}{c}534 \text { men (267 HIV+ and } 267 \mathrm{HIV}-) \\
\text { METH use was not } \\
\text { individually reported }\end{array}$ & $\begin{array}{l}\text { Frequent METH use, but not HIV status, was } \\
\text { associated with persistence of depressive symptoms. }\end{array}$ \\
\hline \multicolumn{4}{|c|}{ Rodent Studies } \\
\hline Kesby et al., 2018 [135] & Cross-sectional & $\begin{array}{l}\text { Doxycycline-inducible HIV-1 Tat } \\
\text { transgenic mouse model }\end{array}$ & $\begin{array}{l}\text { The combination of Tat expression and METH } \\
\text { exposure did not induce significant learning deficits } \\
\text { but did increase perseverations at the initiation of } \\
\text { reversal learning suggesting slight impairments in } \\
\text { executive function. }\end{array}$ \\
\hline Nookala et al., 2018 [136] & Cross-sectional & $\begin{array}{l}\text { Doxycycline-inducible HIV-1 Tat } \\
\text { transgenic mouse model }\end{array}$ & $\begin{array}{l}\text { Administration of METH to HIV-1 Tat transgenic } \\
\text { mice exacerbated the deficits in spatial learning and } \\
\text { memory characterized by decreased spontaneous } \\
\text { alternations in Y maze and increased latency time to } \\
\text { reach the escape platform in the Morris water maze. }\end{array}$ \\
\hline Walter et al., 2021 [138] & Cross-sectional & $\begin{array}{l}\text { Doxycycline-inducible HIV-1 Tat } \\
\text { transgenic mouse model }\end{array}$ & $\begin{array}{l}\text { Chronic METH treatment and Tat expression did not } \\
\text { interact to affect prepulse inhibition in mice. }\end{array}$ \\
\hline Kesby et al., 2016 [144] & Cross-sectional & $\begin{array}{l}\text { Doxycycline-inducible HIV-1 Tat } \\
\text { transgenic mouse model }\end{array}$ & $\begin{array}{l}\text { Tat expression in mice led to reward deficits, a core } \\
\text { symptom of depression, and a greater sensitivity to } \\
\text { METH-induced reward enhancement. }\end{array}$ \\
\hline Kesby et al., 2019 [145] & Cross-sectional & $\begin{array}{l}\text { Doxycycline-inducible HIV-1 Tat } \\
\text { transgenic mouse model }\end{array}$ & $\begin{array}{l}\text { Longer-term Tat expression, or its induction at earlier } \\
\text { stages of METH exposure, was more consequential } \\
\text { at inducing behavioral and neurochemical effects. }\end{array}$ \\
\hline
\end{tabular}

Sustained attention and vigilance are key components of situational awareness and underlie other cognitive functions, such as working memory and learning. While METH use has been found to be associated with sustained attention and vigilance deficits in humans, no interaction between HIV-1 and METH effects were found in a recent study [137]. Furthermore, prepulse inhibition (PPI) of the acoustic startle response, a measure of sensorimotor gating, has been reported to be the lowest in people with HIV-1 who also had a history of METH dependence [138]. These observations suggest that HIV-1 and METH may additively impair early information processing, potentially affecting downstream cognitive function. It has also been demonstrated that the lower levels of PPI were associated with worse performance on cognitive measures, tapping attention, and processing speed in patients with Parkinson's disease [146].

Neurocognitive deficits are thought to substantially impact the ability to engage in the vital tasks of daily living. Although comorbid HIV-1 infection and METH dependence have been associated with worsening cognitive performance, additive effects of HIV-1 and METH were not observed for everyday functioning [139]. Results from two recent human studies demonstrated that individuals with comorbid HIV-1 and METH use disorder exhibited the highest rates of frailty (state of increased vulnerability to multisystem damage) and significantly poorer sleep quality compared to singly affected (HIV-/METH+ and HIV+/METH-) groups [140,141]. Moreover, disrupted sleep and frailty were associated with multiple adverse functional outcomes, including dependence in instrumental activities of daily living and poor ART adherence. Worse self-reported sleep was also found to be associated with greater hippocampal volume reduction across the adult lifespan [147]. In addition, sleep disturbances may be an underlying neurobiological mechanism of 
depression. While one study found the highest prevalence of lifetime major depression disorder in HIV+/METH+ individuals [142], the other study established that METH use was a more important determinant of depression than HIV-1 status [143]. In mouse studies, brain-specific Tat expression led not only to reward deficits, a core symptom of depression, but also to increasing METH-induced reward sensitivity [144,145]. However, it was also reported that the interaction between Tat and METH broadly prevented the METH-induced sensitization [148].

\section{Developing New Therapeutic Approaches for Comorbid HIV-1 Infection and METH Use Disorder}

With the great variety of impacts on the brain caused by HIV-1 infection, and further amplification when coupled with METH abuse, many novel treatments have arisen and continue to be developed to treat specific or multiple impairments. Depression was found to be decreased following consistent administration of mirtazapine [149], as well as by encouraging treatment adherence through the development of a personalized reminder text system [150]. The antioxidant $\mathrm{N}$-acetylcysteine amide has been shown to diminish oxidative stress and protect against autophagy [36], while the steroid ginsenoside Rb1 has been observed to maintain BBB integrity in these circumstances [39]. Gastrodin, an active compound derived from an orchid, appears to be capable of protecting the cells of the NVU from a cascade of effects caused by HIV-1 infection and METH, including an increase in TJ protein expression to maintain BBB integrity [34]. The development of new nanoformulations is also creating unique treatment options, offering patients more targeted drug delivery options with lower risks of cytotoxic effects $[88,151]$. The simplest means of treatment may ultimately prove to be the most effective, as new programs to encourage adherence to existing treatment regimens through text messaging are proving to reduce detrimental behavior, as well as increase rates of adherence to treatment protocols [150,152-154].

\section{Conclusions and Future Prospects}

The combined effects of HIV-1 infection and METH use on the NVU can be deleterious and contribute to the clinical complexity of HAND. Indeed, HIV-1 infection and METH use disorder have a striking synergistic impact on NVU dysfunction and BBB damage, by inducing vascular oxidative stress, increasing the degradation of TJs and basement membrane proteins, and inhibiting nutrient and drug transporters. The impairments in astrocytic glutamate clearance and in the release of proinflammatory mediators and neurotrophic factors are potentiated in HIV-1 and METH comorbidity, and may lead to compromised synaptic functions along with neuronal cell death. The synergistic induction of mitochondrial dysfunction and apoptosis by HIV-1 and METH occurs in both neurons and astrocytes, despite the fact that these NVU cell types preferentially use different metabolic pathways. Disruption of the BBB by the combination of METH and HIV-1 may be related to the release of proinflammatory and neurotoxic mediators not only by glial cells but also by pericytes. Thus, future studies examining the mechanisms of BBB disruption and neuroinflammation mediated by pericytes during co-morbid METH abuse and HIV-1 infection are warranted.

A focus on the NVU for potential drug targets may be helpful to develop novel NVUtargeted therapies in HAND aggravated by METH use. In this regard, TRPM2 channels in brain endothelial cells may serve as a promising drug intervention target to reduce BBB injury and neuropsychiatric symptoms in HIV-1-infected METH abusers. Targeting the EAAT2/TAAR1 pathway in astrocytes could also represent a promising strategy to reduce the accumulation of extracellular glutamate and ameliorate neuronal injury. There is a strong need for in vivo studies addressing the association not only between cognitive impairment and neuronal injury induced by the combination of METH use and HIV-1 but also between BBB breakdown and cognitive disturbances in this pathology. Although most of the studies analyzed in this review were performed in the absence of ART, it is imperative for future studies to characterize the interactive effects of not only METH and HIV-1, but also of antiretroviral therapeutics. 
The coupling of METH misuse with HIV-1 infection is characterized by worsening neurocognitive deficits in executive functions, working memory, and to a lesser degree in learning. Impairment in executive functions such as planning or self-regulation may contribute to medication nonadherence, whereas the association between METH use and risky sexual behavior can be mediated by impaired executive functions in HIV-1 infection. Moreover, alterations in dopamine receptor density or availability that are synergistically induced by METH use and HIV-1 may be especially harmful because they can promote addictive behaviors, such as impulsivity or cravings, and facilitate the development of depression symptoms. The findings from these studies lay the groundwork for future longitudinal research, examining whether frailty and disrupted sleep predict onset of neurocognitive decline in individuals with comorbid HIV-1 and METH use disorder. Furthermore, psychosocial treatments as well as the use of a variety of emerging technologies, such as online social networking and mobile technologies, should be utilized in conjunction with pharmacotherapy to target METH use and improve cognitive functioning in HAND.

Author Contributions: All the authors reviewed the literature and wrote the manuscript. All authors have read and agreed to the published version of the manuscript.

Funding: This work was supported by the National Institutes of Health (NIH), grants DA050528, DA044579, DA039576, DA040537, DA047157, MH072567, MH128022, MH122235, HL126559, and by the NSC grant 2019/35/B/NZ7/03155. Torices was supported by an American Heart Association (AHA) postdoctoral fellowship (20POST35211181).

Institutional Review Board Statement: Not applicable.

Informed Consent Statement: Not applicable.

Data Availability Statement: Not applicable.

Conflicts of Interest: The authors declare no conflict of interest.

\section{References}

1. Ahmad, A.; Neelamegam, M.; Rajasuriar, R. Ageing with HIV: Health implications and evolving care needs. J. Int. AIDS Soc. 2020, 23, e25621. [CrossRef]

2. Wang, Y.; Liu, M.; Lu, Q.; Farrell, M.; Lappin, J.M.; Shi, J.; Lu, L.; Bao, Y. Global prevalence and burden of HIV-associated neurocognitive disorder: A meta-analysis. Neurology 2020, 95, e2610-e2621. [CrossRef] [PubMed]

3. Bertrand, L.; Cho, H.J.; Toborek, M. Blood-brain barrier pericytes as a target for HIV-1 infection. Brain 2019, $142,502-511$. [CrossRef] [PubMed]

4. Lutgen, V.; Narasipura, S.D.; Barbian, H.J.; Richards, M.; Wallace, J.; Razmpour, R.; Buzhdygan, T.; Ramirez, S.H.; Prevedel, L.; Eugenin, E.A.; et al. HIV infects astrocytes in vivo and egresses from the brain to the periphery. PLoS Pathog. 2020, 16, e1008381. [CrossRef]

5. Wallet, C.; De Rovere, M.; Van Assche, J.; Daouad, F.; De Wit, S.; Gautier, V.; Mallon, P.W.G.; Marcello, A.; Van Lint, C.; Rohr, O.; et al. Microglial Cells: The Main HIV-1 Reservoir in the Brain. Front. Cell. Infect. Microbiol. 2019, 9, 362. [CrossRef] [PubMed]

6. Zayyad, Z.; Spudich, S. Neuropathogenesis of HIV: From Initial Neuroinvasion to HIV-Associated Neurocognitive Disorder (HAND). Curr. HIV/AIDS Rep. 2015, 12, 16-24. [CrossRef]

7. Mazzuca, P.; Caruso, A.; Caccuri, F. HIV-1 infection, microenvironment and endothelial cell dysfunction. New Microbiol. 2016, 39, 163-173.

8. Porter, K.M.; Sutliff, R.L. HIV-1, reactive oxygen species, and vascular complications. Free Radic. Biol. Med. 2012, 53, 143-159. [CrossRef]

9. Kovalevich, J.; Langford, D. Neuronal toxicity in HIV CNS disease. Future Virol. 2012, 7, 687-698. [CrossRef]

10. Nath, A.; Haughey, N.J.; Jones, M.; Anderson, C.; Bell, J.E.; Geiger, J.D. Synergistic Neurotoxicity by Human Immunodeficiency Virus Proteins Tat and gp120: Protection by Memantine. Ann. Neurol. 2000, 47, 186-194. [CrossRef]

11. Saylor, D.; Dickens, A.M.; Sacktor, N.; Haughey, N.; Slusher, B.; Pletnikov, M.; Mankowski, J.L.; Brown, A.; Volsky, D.J.; McArthur, J.C. HIV-associated neurocognitive disorder-Pathogenesis and prospects for treatment. Nat. Rev. Neurol. 2016, 12, 234-248. [CrossRef]

12. Van Marle, G.; Henry, S.; Todoruk, T.; Sullivan, A.; Silva, C.; Rourke, S.B.; Holden, J.; McArthur, J.C.; Gill, M.J.; Power, C. Human immunodeficiency virus type 1 Nef protein mediates neural cell death: A neurotoxic role for IP-10. Virology 2004, 329, 302-318. [CrossRef]

13. Nerlander, L.M.C.; Hoots, B.E.; Bradley, H.; Broz, D.; Thorson, A.; Paz-Bailey, G. HIV infection among MSM who inject methamphetamine in 8 US cities. Drug Alcohol Depend. 2018, 190, 216-223. [CrossRef] [PubMed] 
14. Cai, Y.; Dai, Z.; Wen, S.; Bhandari, R. Risk factors associated with infection of blood-borne virus among people who used methamphetamine. BMC Infect. Dis. 2020, 20,1-11. [CrossRef] [PubMed]

15. Glick, S.N.; Burt, R.; Kummer, K.; Tinsley, J.; Banta-Green, C.J.; Golden, M.R. Increasing methamphetamine injection among non-MSM who inject drugs in King County, Washington. Drug Alcohol Depend. 2018, 182, 86-92. [CrossRef]

16. Hoenigl, M.; Chaillon, A.; Moore, D.J.; Morris, S.R.; Smith, D.M.; Little, S.J. Clear links between starting methamphetamine and increasing sexual risk behavior: A cohort study among men who have sex with men. J. Acquir. Immune Defic. Syndr. 2016, 71, 551-557. [CrossRef]

17. Noroozi, M.; Higgs, P.; Noroozi, A.; Armoon, B.; Mousavi, B.; Alikhani, R.; Bazrafshan, M.R.; Astaneh, A.N.; Bayani, A.; Moghaddam, L.F. Methamphetamine use and HIV risk behavior among men who inject drugs: Causal inference using coarsened exact matching. Harm Reduct. J. 2020, 17, 1-7. [CrossRef]

18. Feelemyer, J.; Arasteh, K.; Huong, D.T.; Oanh, K.T.H.; Khue, P.M.; Giang, H.T.; Thanh, N.T.T.; Moles, J.P.; Vinh, V.H.; Vallo, R.; et al. Associations between methamphetamine use and lack of viral suppression among a cohort of HIV-positive persons who inject drugs in Hai Phong, Vietnam. AIDS 2020, 34, 1875-1882. [CrossRef]

19. Fulcher, J.A.; Javanbakht, M.; Shover, C.L.; Ragsdale, A.; Brookmeyer, R.; Shoptaw, S.; Gorbach, P.M. Comparative impact of methamphetamine and other drug use on viral suppression among sexual minority men on antiretroviral therapy. Drug Alcohol Depend. 2021, 221, 108622. [CrossRef] [PubMed]

20. Miller, M.; Lee, J.Y.; Fulcher, J.A.; Roach, M.E.; Dilworth, S.E.; Chahine, A.; Pallikkuth, S.; Fuchs, D.; Pahwa, S.; Carrico, A.W. Getting to the point: Methamphetamine injection is associated with biomarkers relevant to HIV pathogenesis. Drug Alcohol Depend. 2020, 213, 108133. [CrossRef]

21. Sanchez, A.B.; Kaul, M. Neuronal stress and injury caused by HIV-1, cART and drug abuse: Converging contributions to HAND. Brain Sci. 2017, 7, 25. [CrossRef] [PubMed]

22. Soontornniyomkij, V.; Umlauf, A.; Soontornniyomkij, B.; Batki, I.B.; Moore, D.J.; Masliah, E.; Achim, C.L. Lifetime methamphetamine dependence is associated with cerebral microgliosis in HIV-1 infected adults. J. Neurovirol. 2016, 22, 650. [CrossRef] [PubMed]

23. Basova, L.; Lindsey, A.; McGovern, A.M.; Ellis, R.J.; Marcondes, M.C.G. Detection of h3k4me3 identifies neurohiv signatures, genomic effects of methamphetamine and addiction pathways in postmortem hiv+ brain specimens that are not amenable to transcriptome analysis. Viruses 2021, 13, 544. [CrossRef]

24. Geng, J.; Wang, L.; Zhang, L.; Qin, C.; Song, Y.; Ma, Y.; Chen, Y.; Chen, S.; Wang, Y.; Zhang, Z.; et al. Blood-brain barrier disruption induced cognitive impairment is associated with increase of inflammatory cytokine. Front. Aging Neurosci. 2018, 10, 129. [CrossRef]

25. Nation, D.A.; Sweeney, M.D.; Montagne, A.; Sagare, A.P.; D'Orazio, L.M.; Pachicano, M.; Sepehrband, F.; Nelson, A.R.; Buennagel, D.P.; Harrington, M.G.; et al. Blood-brain barrier breakdown is an early biomarker of human cognitive dysfunction. Nat. Med. 2019, 25, 270-276. [CrossRef] [PubMed]

26. Atluri, V.S.R.; Hidalgo, M.; Samikkannu, T.; Venkata Kurapati, K.R.; Jayant, R.D.; Sagar, V.; Nair, M.P.N. Effect of human immunodeficiency virus on blood-brain barrier integrity and function: An update. Front. Cell. Neurosci. 2015, 9, 1-10. [CrossRef]

27. Louboutin, J.P.; Strayer, D.S. Blood-brain barrier abnormalities caused by HIV-1 gp120: Mechanistic and therapeutic implications. Sci. World J. 2012, 2012. [CrossRef]

28. Sajja, R.K.; Rahman, S.; Cucullo, L. Drugs of abuse and blood-brain barrier endothelial dysfunction: A focus on the role of oxidative stress. J. Cereb. Blood Flow Metab. 2016, 36, 539-554. [CrossRef]

29. Yang, X.; Wang, Y.; Li, Q.; Zhong, Y.; Chen, L.; Du, Y.; He, J.; Liao, L.; Xiong, K.; Yi, C.X.; et al. The main molecular mechanisms underlying methamphetamine-induced neurotoxicity and implications for pharmacological treatment. Front. Mol. Neurosci. 2018, 11, 186. [CrossRef]

30. Bell, A.H.; Miller, S.L.; Castillo-Melendez, M.; Malhotra, A. The Neurovascular Unit: Effects of Brain Insults During the Perinatal Period. Front. Neurosci. 2020, 13, 1452. [CrossRef] [PubMed]

31. Burbelo, P.D.; Price, R.W.; Hagberg, L.; Hatano, H.; Spudich, S.; Deeks, S.G.; Gisslén, M. Anti-Human Immunodeficiency Virus Antibodies in the Cerebrospinal Fluid: Evidence of Early Treatment Impact on Central Nervous System Reservoir? J. Infect. Dis. 2018, 217, 1024. [CrossRef] [PubMed]

32. Henderson, L.J.; Johnson, T.P.; Smith, B.R.; Reoma, L.B.; Santamaria, U.A.; Bachani, M.; Demarino, C.; Barclay, R.A.; Snow, J.; Sacktor, N.; et al. Presence of Tat and transactivation response element in spinal fluid despite antiretroviral therapy. AIDS 2019, 33 (Suppl. 2), S145-S157. [CrossRef]

33. Thaney, V.E.; Sanchez, A.B.; Fields, J.A.; Minassian, A.; Young, J.W.; Maung, R.; Kaul, M. Transgenic mice expressing HIV-1 envelope protein gp120 in the brain as an animal model in neuroAIDS research. J. Neurovirol. 2018, 24, 156-167. [CrossRef]

34. Li, J.; Huang, J.; He, Y.; Wang, W.; Leung, C.-K.; Zhang, D.; Zhang, R.; Wang, S.; Li, Y.; Liu, L.; et al. The protective effect of gastrodin against the synergistic effect of HIV-Tat protein and METH on the blood-brain barrier via glucose transporter 1 and glucose transporter 3. Toxicol. Res. 2021, 10, 91-101. [CrossRef] [PubMed]

35. Huang, J.; Zhang, R.; Wang, S.; Zhang, D.; Leung, C.K.; Yang, G.; Li, Y.; Liu, L.; Xu, Y.; Lin, S.; et al. Methamphetamine and HIV-Tat Protein Synergistically Induce Oxidative Stress and Blood-Brain Barrier Damage via Transient Receptor Potential Melastatin 2 Channel. Front. Pharmacol. 2021, 12, 619436. [CrossRef] 
36. Zeng, X.F.; Li, Q.; Li, J.; Wong, N.; Li, Z.; Huang, J.; Yang, G.; Sham, P.C.; Li, S.-B.; Lu, G. HIV-1 Tat and methamphetamine co-induced oxidative cellular injury is mitigated by $\mathrm{N}$-acetylcysteine amide (NACA) through rectifying mTOR signaling. Toxicol. Lett. 2018, 299, 159-171. [CrossRef] [PubMed]

37. Park, M.; Baker, W.; Cambow, D.; Gogerty, D.; Leda, A.R.; Herlihy, B.; Pavlenko, D.; Van Den Nieuwenhuizen, S.; Toborek, M. Methamphetamine Enhances HIV-Induced Aberrant Proliferation of Neural Progenitor Cells via the FOXO3-Mediated Mechanism. Mol. Neurobiol. 2021, 1-16. [CrossRef]

38. Yu, C.; Narasipura, S.D.; Richards, M.H.; Hu, X.T.; Yamamoto, B.; Al-Harthi, L. HIV and drug abuse mediate astrocyte senescence in a $\beta$-catenin-dependent manner leading to neuronal toxicity. Aging Cell 2017, 16, 956-965. [CrossRef] [PubMed]

39. Li, J.; Zeng, B.; Hu, X.; Li, Z.; Zhang, D.; Yang, G.; Dai, J.; Zeng, X. Protective effects of ginsenoside Rb1 against blood-brain barrier damage induced by human immunodeficiency virus-1 tat protein and methamphetamine in Sprague-Dawley rats. Am. J. Chin. Med. 2018, 46, 551-566. [CrossRef] [PubMed]

40. Hoefer, M.M.; Sanchez, A.B.; Maung, R.; de Rozieres, C.M.; Catalan, I.C.; Dowling, C.C.; Thaney, V.E.; Piña-Crespo, J.; Zhang, D.; Roberts, A.J.; et al. Combination of methamphetamine and HIV-1 gp120 causes distinct long-term alterations of behavior, gene expression, and injury in the central nervous system. Exp. Neurol. 2015, 263, 221-234. [CrossRef]

41. De Guglielmo, G.; Fu, Y.; Chen, J.; Larrosa, E.; Hoang, I.; Kawamura, T.; Lorrai, I.; Zorman, B.; Bryant, J.; George, O.; et al. Increases in compulsivity, inflammation, and neural injury in HIV transgenic rats with escalated methamphetamine self-administration under extended-access conditions. Brain Res. 2020, 1726, 146502. [CrossRef]

42. Yu, S.; Zhu, L.; Shen, Q.; Bai, X.; Di, X. Recent advances in methamphetamine neurotoxicity mechanisms and its molecular pathophysiology. Behav. Neurol. 2015, 2015. [CrossRef]

43. Ohene-Nyako, M.; Persons, A.L.; Napier, T.C. Region-specific changes in markers of neuroplasticity revealed in HIV-1 transgenic rats by low-dose methamphetamine. Brain Struct. Funct. 2018, 223, 3503-3513. [CrossRef]

44. Najera, J.A.; Bustamante, E.A.; Bortell, N.; Morsey, B.; Fox, H.S.; Ravasi, T.; Marcondes, M.C.G. Methamphetamine abuse affects gene expression in brain-derived microglia of SIV-infected macaques to enhance inflammation and promote virus targets. $B M C$ Immunol. 2016, 17, 1-19. [CrossRef]

45. Niu, M.; Morsey, B.; Lamberty, B.G.; Emanuel, K.; Yu, F.; León-Rivera, R.; Berman, J.W.; Gaskill, P.J.; Matt, S.M.; Ciborowski, P.S.; et al. Methamphetamine increases the proportion of siv-infected microglia/macrophages, alters metabolic pathways, and elevates cell death pathways: A single-cell analysis. Viruses 2020, 12, 1297. [CrossRef] [PubMed]

46. Doulias, P.-T.; Nakamura, T.; Scott, H.; McKercher, S.R.; Sultan, A.; Deal, A.; Albertolle, M.; Ischiropoulos, H.; Lipton, S.A. TCA cycle metabolic compromise due to an aberrant S-nitrosoproteome in HIV-associated neurocognitive disorder with methamphetamine use. J. Neurovirol. 2021, 27, 367-378. [CrossRef] [PubMed]

47. Patel, S.; Leibrand, C.R.; Palasuberniam, P.; Couraud, P.O.; Weksler, B.; Jahr, F.M.; McClay, J.L.; Hauser, K.F.; McRae, M.P. Effects of HIV-1 Tat and methamphetamine on blood-brain barrier integrity and function in vitro. Antimicrob. Agents Chemother. 2017, 61, e01307-17. [CrossRef] [PubMed]

48. Cao, L.; Fu, M.; Kumar, S.; Kumar, A. Methamphetamine potentiates HIV-1 gp120-mediated autophagy via beclin-1 and Atg5/7 as a pro-survival response in astrocytes. Cell Death Dis. 2016, 7, e2425. [CrossRef] [PubMed]

49. Castellano, P.; Nwagbo, C.; Martinez, L.R.; Eugenin, E.A. Methamphetamine compromises gap junctional communication in astrocytes and neurons. J. Neurochem. 2016, 137, 561-575. [CrossRef] [PubMed]

50. Teodorof-Diedrich, C.; Spector, S.A. Human Immunodeficiency Virus Type 1 and Methamphetamine-Mediated Mitochondrial Damage and Neuronal Degeneration in Human Neurons. J. Virol. 2020, 94, e00924-20. [CrossRef] [PubMed]

51. Li, J.; Wang, W.; Tong, P.; Leung, C.K.; Yang, G.; Li, Z.; Li, N.; Sun, X.; Han, Y.; Lu, C.; et al. Autophagy Induction by HIV-Tat and Methamphetamine in Primary Midbrain Neuronal Cells of Tree Shrews via the mTOR Signaling and ATG5/ATG7 Pathway. Front. Neurosci. 2018, 12, 921. [CrossRef] [PubMed]

52. Liu, J.; Xu, E.; Tu, G.; Liu, H.; Luo, J.; Xiong, H. Methamphetamine potentiates HIV-1gp120-induced microglial neurotoxic activity by enhancing microglial outward K+ current. Mol. Cell. Neurosci. 2017, 82, 167-175. [CrossRef]

53. Fernandes, N.C.; Sriram, U.; Gofman, L.; Cenna, J.M.; Ramirez, S.H.; Potula, R. Methamphetamine alters microglial immune function through P2X7R signaling. J. Neuroinflamm. 2016, 13, 1-13. [CrossRef] [PubMed]

54. Villabona-Rueda, A.; Erice, C.; Pardo, C.A.; Stins, M.F. The Evolving Concept of the Blood Brain Barrier (BBB): From a Single Static Barrier to a Heterogeneous and Dynamic Relay Center. Front. Cell. Neurosci. 2019, 13, 405. [CrossRef]

55. Stamatovic, S.M.; Johnson, A.M.; Keep, R.F.; Andjelkovic, A.V. Junctional proteins of the blood-brain barrier: New insights into function and dysfunction. Tissue Barriers 2016, 4, e1154641. [CrossRef]

56. Kakogiannos, N.; Ferrari, L.; Giampietro, C.; Scalise, A.A.; Maderna, C.; Ravà, M.; Taddei, A.; Lampugnani, M.G.; Pisati, F.; Malinverno, M.; et al. JAM-A acts via C/EBP- $\alpha$ to promote claudin-5 expression and enhance endothelial barrier function. Circ. Res. 2020, 127, 1056-1073. [CrossRef]

57. Lochhead, J.J.; Yang, J.; Ronaldson, P.T.; Davis, T.P. Structure, Function, and Regulation of the Blood-Brain Barrier Tight Junction in Central Nervous System Disorders. Front. Physiol. 2020, 11, 914. [CrossRef] [PubMed]

58. Arima, M.; Nakao, S.; Yamaguchi, M.; Feng, H.; Fujii, Y.; Shibata, K.; Wada, I.; Kaizu, Y.; Ahmadieh, H.; Ishibashi, T.; et al. Claudin-5 redistribution induced by inflammation leads to anti-VEGF-resistant diabetic macular edema. Diabetes 2020, 69, 981-999. [CrossRef] [PubMed] 
59. Greene, C.; Hanley, N.; Campbell, M. Claudin-5: Gatekeeper of neurological function. Fluids Barriers CNS 2019, 16, 1-15. [CrossRef]

60. Ohene-Nyako, M.; Persons, A.L.; Napier, T.C. Hippocampal blood-brain barrier of methamphetamine self-administering HIV-1 transgenic rats. Eur. J. Neurosci. 2021, 53, 416-429. [CrossRef]

61. Tauber, S.C.; Staszewski, O.; Prinz, M.; Weis, J.; Nolte, K.; Bunkowski, S.; Brück, W.; Nau, R. HIV encephalopathy: Glial activation and hippocampal neuronal apoptosis, but limited neural repair. HIV Med. 2016, 17, 143-151. [CrossRef]

62. Choi, M.R.; Chun, J.W.; Kwak, S.M.; Bang, S.H.; Jin, Y.B.; Lee, Y.; Kim, H.N.; Chang, K.T.; Chai, Y.G.; Lee, S.R.; et al. Effects of acute and chronic methamphetamine administration on cynomolgus monkey hippocampus structure and cellular transcriptome. Toxicol. Appl. Pharmacol. 2018, 355, 68-79. [CrossRef]

63. Weksler, B.; Romero, I.A.; Couraud, P.-O. The hCMEC/D3 cell line as a model of the human blood brain barrier. Fluids Barriers CNS 2013, 10, 1-10. [CrossRef] [PubMed]

64. Melega, W.P.; Cho, A.K.; Harvey, D.; Laćan, G. Methamphetamine blood concentrations in human abusers: Application to pharmacokinetic modeling. Synapse 2007, 61, 216-220. [CrossRef]

65. Fowler, J.S.; Volkow, N.D.; Logan, J.; Alexoff, D.; Telang, F.; Wang, G.-J.; Wong, C.; Ma, Y.; Kriplani, A.; Pradhan, K.; et al. Fast Uptake and Long-Lasting Binding of Methamphetamine in the Human Brain: Comparison with Cocaine. Neuroimage 2008, 43, 756. [CrossRef] [PubMed]

66. Volkow, N.D.; Fowler, J.S.; Wang, G.-J.; Shumay, E.; Telang, F.; Thanos, P.K.; Alexoff, D. Distribution and Pharmacokinetics of Methamphetamine in the Human Body: Clinical Implications. PLoS ONE 2010, 5, e15269. [CrossRef]

67. Zhong, Y.; Zhang, B.; Eum, S.Y.; Toborek, M. HIV-1 Tat triggers nuclear localization of ZO-1 via Rho signaling and cAMP response element-binding protein activation. J. Neurosci. 2012, 32, 143-150. [CrossRef]

68. Huang, W.; András, I.E.; Rha, G.B.; Hennig, B.; Toborek, M. PPAR $\alpha$ and PPAR $\gamma$ protect against HIV-1-induced MMP-9 overexpression via caveolae-associated ERK and Akt signaling. FASEB J. 2011, 25, 3979-3988. [CrossRef]

69. Park, M.; Kim, H.J.; Lim, B.; Wylegala, A.; Toborek, M. Methamphetamine-induced occludin endocytosis is mediated by the Arp2/3 complex-regulated actin rearrangement. J. Biol. Chem. 2013, 288, 33324-33334. [CrossRef]

70. Toborek, M.; Seelbach, M.J.; Rashid, C.S.; András, I.E.; Chen, L.; Park, M.; Esser, K.A. Voluntary exercise protects against methamphetamine-induced oxidative stress in brain microvasculature and disruption of the blood-brain barrier. Mol. Neurodegener. 2013, 8, 1-11. [CrossRef] [PubMed]

71. Toborek, M.; Barger, S.W.; Mattson, M.P.; Barve, S.; McClain, C.J.; Hennig, B. Linoleic acid and TNF- $\alpha$ cross-amplify oxidative injury and dysfunction of endothelial cells. J. Lipid Res. 1996, 37, 123-135. [CrossRef]

72. Toborek, M.; Barger, S.W.; Mattson, M.P.; McClain, C.J.; Hennig, B. Role of glutathione redox cycle in TNF- $\alpha$-mediated endothelial cell dysfunction. Atherosclerosis 1995, 117, 179-188. [CrossRef]

73. Patching, S.G. Glucose Transporters at the Blood-Brain Barrier: Function, Regulation and Gateways for Drug Delivery. Mol. Neurobiol. 2017, 54, 1046-1077. [CrossRef]

74. Xia, M.; Ye, Z.; Shi, Y.; Zhou, L.; Hua, Y. Curcumin improves diabetes mellitus-associated cerebral infarction by increasing the expression of GLUT1 and GLUT3. Mol. Med. Rep. 2018, 17, 1963-1969. [CrossRef]

75. Abdul Muneer, P.M.; Alikunju, S.; Szlachetka, A.M.; Murrin, L.C.; Haorah, J. Impairment of brain endothelial glucose transporter by methamphetamine causes blood-brain barrier dysfunction. Mol. Neurodegener. 2011, 6, 1-13. [CrossRef]

76. Alam, C.; Whyte-Allman, S.K.; Omeragic, A.; Bendayan, R. Role and modulation of drug transporters in HIV-1 therapy. Adv. Drug Deliv. Rev. 2016, 103, 121-143. [CrossRef] [PubMed]

77. Dickens, A.M.; Yoo, S.W.; Chin, A.C.; Xu, J.; Johnson, T.P.; Trout, A.L.; Hauser, K.F.; Haughey, N.J. Chronic low-level expression of HIV-1 Tat promotes a neurodegenerative phenotype with aging. Sci. Rep. 2017, 7, 1-11. [CrossRef]

78. Toborek, M.; Lee, Y.W.; Pu, H.; Malecki, A.; Flora, G.; Garrido, R.; Hennig, B.; Bauer, H.C.; Nath, A. HIV-Tat protein induces oxidative and inflammatory pathways in brain endothelium. J. Neurochem. 2003, 84, 169-179. [CrossRef]

79. Namyen, J.; Permpoonputtana, K.; Nopparat, C.; Tocharus, J.; Tocharus, C.; Govitrapong, P. Protective Effects of Melatonin on Methamphetamine-Induced Blood-Brain Barrier Dysfunction in Rat Model. Neurotox. Res. 2020, 37, 640-660. [CrossRef]

80. Herland, A.; Maoz, B.M.; FitzGerald, E.A.; Grevesse, T.; Vidoudez, C.; Sheehy, S.P.; Budnik, N.; Dauth, S.; Mannix, R.; Budnik, B.; et al. Proteomic and Metabolomic Characterization of Human Neurovascular Unit Cells in Response to Methamphetamine. Adv. Biosyst. 2020, 4, 1900230. [CrossRef] [PubMed]

81. Alawieyah Syed Mortadza, S.; Sim, J.A.; Neubrand, V.E.; Jiang, L.H. A critical role of TRPM2 channel in A $\beta 42$-induced microglial activation and generation of tumor necrosis factor- $\alpha$. Glia 2018, 66, 562-575. [CrossRef]

82. Wang, L.; Negro, R.; Wu, H. TRPM2, linking oxidative stress and Ca2+ permeation to NLRP3 inflammasome activation. Curr. Opin. Immunol. 2020, 62, 131-135. [CrossRef]

83. Jiang, Q.; Gao, Y.; Wang, C.; Tao, R.; Wu, Y.; Zhan, K.; Liao, M.; Lu, N.; Lu, Y.; Wilcox, C.S.; et al. Nitration of TRPM2 as a Molecular Switch Induces Autophagy during Brain Pericyte Injury. Antioxid. Redox Signal. 2017, 27, 1297-1316. [CrossRef]

84. Michinaga, S.; Koyama, Y. Dual roles of astrocyte-derived factors in regulation of blood-brain barrier function after brain damage. Int. J. Mol. Sci. 2019, 20, 571. [CrossRef]

85. Guérit, S.; Fidan, E.; Macas, J.; Czupalla, C.J.; Figueiredo, R.; Vijikumar, A.; Yalcin, B.H.; Thom, S.; Winter, P.; Gerhardt, H.; et al. Astrocyte-derived Wnt growth factors are required for endothelial blood-brain barrier maintenance. Prog. Neurobiol. 2021, 199, 101937. [CrossRef] [PubMed] 
86. Heithoff, B.P.; George, K.K.; Phares, A.N.; Zuidhoek, I.A.; Munoz-Ballester, C.; Robel, S. Astrocytes are necessary for blood-brain barrier maintenance in the adult mouse brain. Glia 2021, 69, 436-472. [CrossRef]

87. Watkins, S.; Robel, S.; Kimbrough, I.F.; Robert, S.M.; Ellis-Davies, G.; Sontheimer, H. Disruption of astrocyte-vascular coupling and the blood-brain barrier by invading glioma cells. Nat. Commun. 2014, 5, 1-15. [CrossRef] [PubMed]

88. Jayant, R.D.; Tiwari, S.; Atluri, V.; Kaushik, A.; Tomitaka, A.; Yndart, A.; Colon-Perez, L.; Febo, M.; Nair, M. Multifunctional Nanotherapeutics for the Treatment of neuroAIDS in Drug Abusers. Sci. Rep. 2018, 8, 1-12. [CrossRef]

89. Sweeney, M.D.; Ayyadurai, S.; Zlokovic, B.V. Pericytes of the neurovascular unit: Key functions and signaling pathways. Nat. Neurosci. 2016, 19, 771-783. [CrossRef] [PubMed]

90. Armulik, A.; Genové, G.; Mäe, M.; Nisancioglu, M.H.; Wallgard, E.; Niaudet, C.; He, L.; Norlin, J.; Lindblom, P.; Strittmatter, K.; et al. Pericytes regulate the blood-brain barrier. Nature 2010, 468, 557-561. [CrossRef] [PubMed]

91. Bohannon, D.G.; Ko, A.; Filipowicz, A.R.; Kuroda, M.J.; Kim, W.K. Dysregulation of sonic hedgehog pathway and pericytes in the brain after lentiviral infection. J. Neuroinflamm. 2019, 16, 1-13. [CrossRef]

92. Bohannon, D.G.; Okhravi, H.R.; Kim, J.; Kuroda, M.J.; Didier, E.S.; Kim, W.K. A subtype of cerebrovascular pericytes is associated with blood-brain barrier disruption that develops during normal aging and simian immunodeficiency virus infection. Neurobiol. Aging 2020, 96, 128-136. [CrossRef]

93. Cho, H.J.; Kuo, A.M.S.; Bertrand, L.; Toborek, M. HIV alters gap junction-mediated intercellular communication in human brain pericytes. Front. Mol. Neurosci. 2017, 10, 410. [CrossRef]

94. Castro, V.; Bertrand, L.; Luethen, M.; Dabrowski, S.; Lombardi, J.; Morgan, L.; Sharova, N.; Stevenson, M.; Blasig, I.E.; Toborek, M. Occludin controls HIV transcription in brain pericytes via regulation of SIRT-1 activation. FASEB J. 2016, 30, 1234-1246. [CrossRef] [PubMed]

95. Torices, S.; Roberts, S.A.; Park, M.; Malhotra, A.; Toborek, M. Occludin, caveolin-1, and Alix form a multi-protein complex and regulate HIV-1 infection of brain pericytes. FASEB J. 2020, 34, 16319-16332. [CrossRef] [PubMed]

96. Zhang, Y.; Zhang, Y.; Bai, Y.; Chao, J.; Hu, G.; Chen, X.; Yao, H. Involvement of PUMA in pericyte migration induced by methamphetamine. Exp. Cell Res. 2017, 356, 28-39. [CrossRef]

97. Piekna-Przybylska, D.; Nagumotu, K.; Reid, D.M.; Maggirwar, S.B. HIV-1 infection renders brain vascular pericytes susceptible to the extracellular glutamate. J. Neurovirol. 2019, 25, 114-126. [CrossRef]

98. Harms, R.; Morsey, B.; Boyer, C.W.; Fox, H.S.; Sarvetnick, N. Methamphetamine Administration Targets Multiple Immune Subsets and Induces Phenotypic Alterations Suggestive of Immunosuppression. PLoS ONE 2012, 7, e49897. [CrossRef]

99. Jiang, J.; Wang, M.; Liang, B.; Shi, Y.; Su, Q.; Chen, H.; Huang, J.; Su, J.; Pan, P.; Li, Y.; et al. In vivo effects of methamphetamine on HIV-1 replication: A population-based study. Drug Alcohol Depend. 2016, 159, 246-254. [CrossRef] [PubMed]

100. Carrico, A.W.; Cherenack, E.M.; Roach, M.E.; Riley, E.D.; Oni, O.; DIlworth, S.E.; Shoptaw, S.; Hunt, P.; Roy, S.; Pallikkuth, S.; et al. Substance-associated elevations in monocyte activation among methamphetamine users with treated HIV infection. AIDS 2018, 32, 767-771. [CrossRef]

101. Liang, H.; Wang, X.; Chen, H.; Song, L.; Ye, L.; Wang, S.H.; Wang, Y.J.; Zhou, L.; Ho, W.Z. Methamphetamine enhances HIV infection of macrophages. Am. J. Pathol. 2008, 172, 1617-1624. [CrossRef] [PubMed]

102. Lawson, K.S.; Prasad, A.; Groopman, J.E. Methamphetamine Enhances HIV-1 Replication in CD4+ T-Cells via a Novel IL-1 $\beta$ Auto-Regulatory Loop. Front. Immunol. 2020, 11, 136. [CrossRef]

103. Prasad, A.; Kulkarni, R.; Shrivastava, A.; Jiang, S.; Lawson, K.; Groopman, J.E. Methamphetamine functions as a novel CD4+ T-cell activator via the sigma-1 receptor to enhance HIV-1 infection. Sci. Rep. 2019, 9, 1-13. [CrossRef] [PubMed]

104. Marcondes, M.C.G.; Flynn, C.; Watry, D.D.; Zandonatti, M.; Fox, H.S. Methamphetamine increases brain viral load and activates natural killer cells in simian immunodeficiency virus-infected monkeys. Am. J. Pathol. 2010, 177, 355-361. [CrossRef]

105. Basova, L.; Najera, J.A.; Bortell, N.; Wang, D.; Moya, R.; Lindsey, A.; Semenova, S.; Ellis, R.J.; Marcondes, M.C.G. Dopamine and its receptors play a role in the modulation of CCR5 expression in innate immune cells following exposure to Methamphetamine: Implications to HIV infection. PLoS ONE 2018, 13, e0199861. [CrossRef] [PubMed]

106. Brilha, S.; Ong, C.W.M.; Weksler, B.; Romero, N.; Couraud, P.O.; Friedland, J.S. Matrix metalloproteinase-9 activity and a downregulated Hedgehog pathway impair blood-brain barrier function in an in vitro model of CNS tuberculosis. Sci. Rep. 2017, 7, 1-15. [CrossRef]

107. Rosell, A.; Cuadrado, E.; Ortega-Aznar, A.; Hernández-Guillamon, M.; Lo, E.H.; Montaner, J. MMP-9-positive neutrophil infiltration is associated to blood-brain barrier breakdown and basal lamina type IV collagen degradation during hemorrhagic transformation after human ischemic stroke. Stroke 2008, 39, 1121-1126. [CrossRef]

108. Agrawal, S.; Anderson, P.; Durbeej, M.; Van Rooijen, N.; Ivars, F.; Opdenakker, G.; Sorokin, L.M. Dystroglycan is selectively cleaved at the parenchymal basement membrane at sites of leukocyte extravasation in experimental autoimmune encephalomyelitis. $J$. Exp. Med. 2006, 203, 1007-1016. [CrossRef]

109. Huang, W.; Chen, L.; Zhang, B.; Park, M.; Toborek, M. PPAR agonist-mediated protection against HIV Tat-induced cerebrovascular toxicity is enhanced in MMP-9-deficient mice. J. Cereb. Blood Flow Metab. 2014, 34, 646-653. [CrossRef]

110. Pu, H.; Hayashi, K.; Andras, I.E.; Eum, S.Y.; Hennig, B.; Toborek, M. Limited role of COX-2 in HIV Tat-induced alterations of tight junction protein expression and disruption of the blood-brain barrier. Brain Res. 2007, 1184, 333-344. [CrossRef]

111. Northrop, N.A.; Yamamoto, B.K. Persistent neuroinflammatory effects of serial exposure to stress and methamphetamine on the blood-brain barrier. J. Neuroimmune Pharmacol. 2012, 7, 951-968. [CrossRef] 
112. Wu, Y.T.; Gilpin, K.; Adnan, A. Effects of Focal Axonal Swelling Level on the Action Potential Signal Transmission. J. Comput. Neurosci. 2020, 48, 253-263. [CrossRef] [PubMed]

113. Byun, N.; Delpire, E. Axonal and periaxonal swelling precede peripheral neurodegeneration in KCC3 knockout mice. Neurobiol. Dis. 2007, 28, 39-51. [CrossRef] [PubMed]

114. Alvarez-Carbonell, D.; Ye, F.; Ramanath, N.; Garcia-Mesa, Y.; Knapp, P.E.; Hauser, K.F.; Karn, J. Cross-talk between microglia and neurons regulates HIV latency. PLoS Pathog. 2019, 15, e1008249. [CrossRef]

115. Mediouni, S.; Garibaldi Marcondes, M.C.; Miller, C.; McLaughlin, J.P.; Valente, S.T. The cross-talk of HIV-1 Tat and methamphetamine in HIV-associated neurocognitive disorders. Front. Microbiol. 2015, 6, 1164. [CrossRef]

116. Rangaraju, V.; Lauterbach, M.; Schuman, E.M. Spatially Stable Mitochondrial Compartments Fuel Local Translation during Plasticity. Cell 2019, 176, 73-84. [CrossRef] [PubMed]

117. Kallianpur, K.J.; Walker, M.; Gerschenson, M.; Shikuma, C.M.; Gangcuangco, L.M.A.; Kohorn, L.; Libutti, D.E.; Nir, T.M.; Jahanshad, N.; Thompson, P.M.; et al. Systemic Mitochondrial Oxidative Phosphorylation Protein Levels Correlate with Neuroimaging Measures in Chronically HIV-Infected Individuals. AIDS Res. Hum. Retrovir. 2020, 36, 83-91. [CrossRef] [PubMed]

118. Mehta, S.R.; Iudicello, J.E.; Lin, J.; Ellis, R.J.; Morgan, E.; Okwuegbuna, O.; Cookson, D.; Karris, M.; Saloner, R.; Heaton, R.; et al. Telomere length is associated with HIV infection, methamphetamine use, inflammation, and comorbid disease risk. Drug Alcohol Depend. 2021, 221, 108639. [CrossRef]

119. Fields, J.A.; Serger, E.; Campos, S.; Divakaruni, A.S.; Kim, C.; Smith, K.; Trejo, M.; Adame, A.; Spencer, B.; Rockenstein, E.; et al. HIV alters neuronal mitochondrial fission/fusion in the brain during HIV-associated neurocognitive disorders. Neurobiol. Dis. 2016, 86, 154-169. [CrossRef]

120. Avdoshina, V.; Fields, J.A.; Castellano, P.; Dedoni, S.; Palchik, G.; Trejo, M.; Adame, A.; Rockenstein, E.; Eugenin, E.; Masliah, E.; et al. The HIV Protein gp120 Alters Mitochondrial Dynamics in Neurons. Neurotox. Res. 2016, 29, 583-593. [CrossRef]

121. Tian, C.; Murrin, L.C.; Zheng, J.C. Mitochondrial fragmentation is involved in methamphetamine-induced cell death in rat hippocampal neural progenitor cells. PLoS ONE 2009, 4, e5546. [CrossRef]

122. Skowronska, M.; McDonald, M.; Velichkovska, M.; Rachel Leda, A.; Park, M.; Toborek, M. Methamphetamine increases HIV infectivity in neural progenitor cells. J. Biol. Chem. 2018, 293, 296-311. [CrossRef]

123. Pozhilenkova, E.A.; Lopatina, O.L.; Komleva, Y.K.; Salmin, V.V.; Salmina, A.B. Blood-brain barrier-supported neurogenesis in healthy and diseased brain. Rev. Neurosci. 2017, 28, 397-415. [CrossRef]

124. Nickoloff-Bybel, E.A.; Calderon, T.M.; Gaskill, P.J.; Berman, J.W. HIV Neuropathogenesis in the Presence of a Disrupted Dopamine System. J. Neuroimmune Pharmacol. 2020, 15, 729-742. [CrossRef] [PubMed]

125. Tu, G.; Ying, L.; Ye, L.; Zhao, J.; Liu, N.; Li, J.; Liu, Y.; Zhu, M.; Wu, Y.; Xiao, B.; et al. Dopamine D1 and D2 Receptors Differentially Regulate Rac1 and Cdc42 Signaling in the Nucleus Accumbens to Modulate Behavioral and Structural Plasticity After Repeated Methamphetamine Treatment. Biol. Psychiatry 2019, 86, 820-835. [CrossRef] [PubMed]

126. Hasbi, A.; Sivasubramanian, M.; Milenkovic, M.; Komarek, K.; Madras, B.K.; George, S.R. Dopamine D1-D2 receptor heteromer expression in key brain regions of rat and higher species: Upregulation in rat striatum after cocaine administration. Neurobiol. Dis. 2020, 143, 105017. [CrossRef] [PubMed]

127. Baek, E.J.; Kim, H.; Basova, L.A.; Rosander, A.; Kesby, J.P.; Semenova, S.; Marcondes, M.C.G. Sex differences and Tat expression affect dopaminergic receptor expression and response to antioxidant treatment in methamphetamine-sensitized HIV Tat transgenic mice. Neuropharmacology 2020, 178, 108245. [CrossRef]

128. Ashok, A.H.; Mizuno, Y.; Volkow, N.D.; Howes, O.D. Association of stimulant use with dopaminergic alterations in users of cocaine, amphetamine, or methamphetamine a systematic review and meta-analysis. JAMA Psychiatry 2017, 74, 511-519. [CrossRef]

129. Proebstl, L.; Kamp, F.; Manz, K.; Krause, D.; Adorjan, K.; Pogarell, O.; Koller, G.; Soyka, M.; Falkai, P.; Kambeitz, J. Effects of stimulant drug use on the dopaminergic system: A systematic review and meta-analysis of in vivo neuroimaging studies. Eur. Psychiatry 2019, 59, 15-24. [CrossRef]

130. Borgmann, K.; Ghorpade, A. Methamphetamine augments concurrent astrocyte mitochondrial stress, oxidative burden, and antioxidant capacity: Tipping the balance in HIV-associated neurodegeneration. Neurotox. Res. 2018, 33, 433-447. [CrossRef]

131. Martínez-Cué, C.; Rueda, N. Cellular Senescence in Neurodegenerative Diseases. Front. Cell. Neurosci. 2020, 14, 956-965. [CrossRef]

132. Mahmoud, S.; Gharagozloo, M.; Simard, C.; Gris, D. Astrocytes Maintain Glutamate Homeostasis in the CNS by Controlling the Balance between Glutamate Uptake and Release. Cells 2019, 8, 184. [CrossRef] [PubMed]

133. Cisneros, I.E. Methamphetamine Activates Trace Amine Associated Receptor 1 to Regulate Astrocyte Excitatory Amino Acid Transporter-2 via Differential CREB Phosphorylation During HIV-Associated Neurocognitive Disorders. Front. Neurol. 2020, 11, 1552. [CrossRef]

134. Walker, K.A.; Brown, G.G. HIV-associated executive dysfunction in the era of modern antiretroviral therapy: A systematic review and meta-analysis. J. Clin. Exp. Neuropsychol. 2018, 40, 357-376. [CrossRef]

135. Kesby, J.P.; Fields, J.A.; Chang, A.; Coban, H.; Achim, C.L.; Semenova, S. Effects of HIV-1 TAT protein and methamphetamine exposure on visual discrimination and executive function in mice. Behav. Brain Res. 2018, 349, 73-79. [CrossRef] 
136. Nookala, A.R.; Schwartz, D.C.; Chaudhari, N.S.; Glazyrin, A.; Stephens, E.B.; Berman, N.E.J.; Kumar, A. Methamphetamine augment HIV-1 Tat mediated memory deficits by altering the expression of synaptic proteins and neurotrophic factors. Brain. Behav. Immun. 2018, 71, 37-51. [CrossRef] [PubMed]

137. Pocuca, N.; Young, J.W.; MacQueen, D.A.; Letendre, S.; Heaton, R.K.; Geyer, M.A.; Perry, W.; Grant, I.; Minassian, A. Sustained attention and vigilance deficits associated with HIV and a history of methamphetamine dependence. Drug Alcohol Depend. 2020, 215, 108245. [CrossRef] [PubMed]

138. Walter, T.J.; Young, J.W.; Milienne-Petiot, M.; Deben, D.S.; Heaton, R.K.; Letendre, S.; Grelotti, D.J.; Perry, W.; Grant, I.; Minassian, A. Both HIV and Tat expression decrease prepulse inhibition with further impairment by methamphetamine. Prog. NeuroPsychopharmacol. Biol. Psychiatry 2021, 106, 110089. [CrossRef] [PubMed]

139. Minassian, A.; Henry, B.L.; Iudicello, J.E.; Morgan, E.E.; Letendre, S.L.; Heaton, R.K.; Perry, W. Everyday functional ability in HIV and methamphetamine dependence. Drug Alcohol Depend. 2017, 175, 60-66. [CrossRef]

140. Paolillo, E.W.; Saloner, R.; Montoya, J.L.; Campbell, L.M.; Pasipanodya, E.C.; Iudicello, J.E.; Moore, R.C.; Letendre, S.L.; Jeste, D.V.; Moore, D.J. Frailty in comorbid HIV and lifetime methamphetamine use disorder: Associations with neurocognitive and everyday functioning. AIDS Res. Hum. Retrovir. 2019, 35, 1044-1053. [CrossRef]

141. Sun-Suslow, N.; Saloner, R.; Serrano, V.; Umlauf, A.; Morgan, E.E.; Ellis, R.J.; Letendre, S.; Grant, I.; Heaton, R.K. Lifetime Methamphetamine Use Disorder and Reported Sleep Quality in Adults Living with HIV. AIDS Behav. 2020, 24, $3071-3082$. [CrossRef]

142. Saloner, R.; Cherner, M.; Iudicello, J.E.; Heaton, R.K.; Letendre, S.L.; Ellis, R.J. Cerebrospinal Fluid Norepinephrine and Neurocognition in HIV and Methamphetamine Dependence. J. Acquir. Immune Defic. Syndr. 2020, 85, e12-e22. [CrossRef] [PubMed]

143. Javanbakht, M.; Shoptaw, S.; Ragsdale, A.; Brookmeyer, R.; Bolan, R.; Gorbach, P.M. Depressive symptoms and substance use: Changes overtime among a cohort of HIV-positive and HIV-negative MSM. Drug Alcohol Depend. 2020, 207, 107770. [CrossRef]

144. Kesby, J.P.; Markou, A.; Semenova, S. The effects of HIV-1 regulatory TAT protein expression on brain reward function, response to psychostimulants and delay-dependent memory in mice. Neuropharmacology 2016, 109, 205-215. [CrossRef] [PubMed]

145. Kesby, J.P.; Chang, A.; Najera, J.A.; Marcondes, M.C.G.; Semenova, S. Brain Reward Function after Chronic and Binge Methamphetamine Regimens in Mice Expressing the HIV-1 TAT Protein. Curr. HIV Res. 2019, 17, 126-133. [CrossRef]

146. Zoetmulder, M.; Biernat, H.B.; Nikolic, M.; Korbo, L.; Friberg, L.; Jennum, P.J. Prepulse inhibition is associated with attention, processing speed, and 123I-FP-CIT SPECT in Parkinson's Disease. J. Parkinson's Dis. 2014, 4, 77-87. [CrossRef]

147. Fjell, A.M.; Sørensen, Ø.; Amlien, I.K.; Bartrés-Faz, D.; Bros, D.M.; Buchmann, N.; Demuth, I.; Drevon, C.A.; Düzel, S.; Ebmeier, K.P.; et al. Self-reported sleep relates to hippocampal atrophy across the adult lifespan: Results from the lifebrain consortium. Sleep 2020, 43, zsz280. [CrossRef]

148. Basova, L.V.; Kesby, J.P.; Kaul, M.; Semenova, S.; Marcondes, M.C.G. Systems biology analysis of the antagonizing effects of HIV-1 Tat expression in the brain over transcriptional changes caused by methamphetamine sensitization. Viruses 2020, $12,426$. [CrossRef] [PubMed]

149. Coffin, P.O.; Santos, G.M.; Hern, J.; Vittinghoff, E.; Walker, J.E.; Matheson, T.; Santos, D.; Colfax, G.; Batki, S.L. Effects of Mirtazapine for Methamphetamine Use Disorder among Cisgender Men and Transgender Women Who Have Sex with Men: A Placebo-Controlled Randomized Clinical Trial. JAMA Psychiatry 2020, 77, 246-255. [CrossRef]

150. Moore, D.J.; Pasipanodya, E.C.; Umlauf, A.; Rooney, A.S.; Gouaux, B.; Depp, C.A.; Atkinson, J.H.; Montoya, J.L. Individualized texting for adherence building (iTAB) for methamphetamine users living with HIV: A pilot randomized clinical trial. Drug Alcohol Depend. 2018, 189, 154-160. [CrossRef]

151. Jayant, R.D.; Atluri, V.S.R.; Tiwari, S.; Pilakka-Kanthikeel, S.; Kaushik, A.; Yndart, A.; Nair, M. Novel nanoformulation to mitigate co-effects of drugs of abuse and HIV-1 infection: Towards the treatment of NeuroAIDS. J. Neurovirol. 2017, 23, 603-614. [CrossRef] [PubMed]

152. McMahan, V.M.; Frank, N.; Buckler, S.; Violette, L.R.; Baeten, J.M.; Banta-Green, C.J.; Barnabas, R.V.; Simoni, J.; Stekler, J.D. Protocol development for HMU! (HIV prevention for methamphetamine users), a study of peer navigation and text messaging to promote pre-exposure prophylaxis adherence and persistence among people who use methamphetamine: Qualitative focus group and intervi. JMIR Form. Res. 2020, 4, e18118. [CrossRef]

153. Pasipanodya, E.C.; Kohli, M.; Kohli, M.; Fisher, C.B.; Moore, D.J.; Curtis, B. Perceived risks and amelioration of harm in research using mobile technology to support antiretroviral therapy adherence in the context of methamphetamine use: A focus group study among minorities living with HIV. Harm Reduct. J. 2020, 17, 1-11. [CrossRef] [PubMed]

154. Reback, C.J.; Fletcher, J.B.; Swendeman, D.A.; Metzner, M. Theory-Based Text-Messaging to Reduce Methamphetamine Use and HIV Sexual Risk Behaviors Among Men Who Have Sex with Men: Automated Unidirectional Delivery Outperforms Bidirectional Peer Interactive Delivery. AIDS Behav. 2019, 23, 37-47. [CrossRef] [PubMed] 